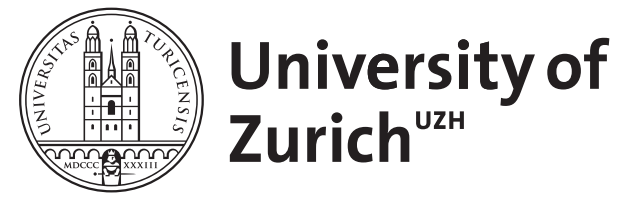

\title{
Business Cycles and Economic Policy, 1914-1945
}

Ritschl, Albrecht ; Straumann, Tobias

DOI: https://doi.org/10.2307/2551028

Posted at the Zurich Open Repository and Archive, University of Zurich ZORA URL: https://doi.org/10.5167/uzh-46452

Book Section

Originally published at:

Ritschl, Albrecht; Straumann, Tobias (2010). Business Cycles and Economic Policy, 1914-1945. In: Broadberry, Stephen; O'Rourke, Kevin H. The Cambridge economic history of modern Europe: 1870 to the present. Cambridge: Cambridge University Press, 156-180.

DOI: https://doi.org/10.2307/2551028 
Working Papers No. 115/09

\title{
Business Cycles and Economic Policy, 1914-1945: A Survey
}

\author{
Albrecht Ritschl \\ $\&$ \\ Tobias Straumann
}

(C) Albrecht Ritschl, LSE

Tobias Straumann, Zurich 
Department of Economic History London School of Economics Houghton Street London, WC2A $2 \mathrm{AE}$

Tel: $\quad$ +44 (0) 2079557860

Fax: $\quad$ +44 (0) 2079557730 


\section{Business Cycles and Economic Policy, 1914-1945: A Survey}

Albrecht Ritschl and Tobias Straumann

\section{Introduction}

The Great War of 1914-18 constituted a major rupture for the economies of Europe in several respects. It marked the end of almost a century of uninterrupted economic growth. It ended a long period of nearuniversal currency stability, and set in motion a painful process of deglobalisation. It brought about an age of highly politicised labour relations. And it ushered in an era in which sharp fluctuations of economic activity and persistent mass unemployment became the dominant experience of everyday life.

While the beginning of this dramatic period can clearly be identified with World War I, its effects lasted beyond the end of World War II. Throughout the interwar period, the economies of Europe remained far below their historical growth paths. Full recovery from this long-lasting depression occurred only during the Golden Age of the 1960s. But not all of the displacement from historical trends that took place after World War I was ultimately corrected, and some of the changes became permanent. In the more developed economies of Europe, a marked upward shift in labour's income shares occurred after 1918. To this added compression of wages and of the personal income distribution in general. Both favoured low incomes and reduced the shares taken by top earners. Most of these distributional shocks of the early interwar period have been permanent and are still visible in the economies of Europe today. Monetary conditions were also fundamentally altered after World War I. Some of the changes were temporary in nature. Most prominent among these were the dramatic hyperinflations hitting the former Central Powers and their successor states in the early 1920s. Equally temporary were the 
deflationary waves elsewhere in Europe in the early 1920s, and more universally in the early 1930s. Other regime changes in monetary conditions were more permanent, most importantly the aborted attempt to reconstruct the Gold Standard in the 1920s. The traumatic consequences of this experience had far-reaching consequences for the reconstruction of the monetary system after World War II. More persistent in nature was also the notable reduction in the freedom of international capital flows, and later of foreign trade as such.

The period between the World Wars also marked a sea change in macroeconomic policy. In contrast to the $19^{\text {th }}$ century, where modest policy intervention had been the accepted norm, activism in economic policy now became the order of the day. State intervention in the markets for goods, factors of production, and money quickly became widespread. In this context, institutions were created that often acquired constitutional status, in some cases with effects lasting to today. Not all of the policy experiments after World War I were equally long-lived, though. Attempts to achieve monetary stabilisation with paper currencies were quickly abandoned, and an - albeit half-hearted - return to gold took place in the mid-1920s. A second transition to paper currencies in the early 1930 s was only marginally more successful, this time not because of inflation but rather because of increasingly tight capital controls and import quotas which in most parts of Europe suffocated international trade and capital movements. While these trade restrictions were dismantled with relative ease after World War II, only in the 1970s was a solution found that combined regional fixed exchange rate blocs with liberalised capital movements. But still, even today no system is in place that would render the services of the Classical Gold Standard that prevailed before 1914.

Economic planning began as an improvised response to shortages during World War I, but soon acquired systemic character in a number of European countries. Industries were nationalised or supervising state 
agencies created, attempting to exert political control both at the macro and micro levels, and to reduce the exposure of the national economy to business fluctuations. Again, the effects of these changes were longlived, with lasting macroeconomic effects. Deregulation of state-controlled sectors, as well as divestment from state-owned industries, lasted almost to the end of the $20^{\text {th }}$ century. The end of the Soviet system in Eastern Europe, where economic planning and the abolition of private property rights had been driven to the extreme, is but the most evident case in point.

Economic policy was itself a dimension of international conflict during the period of 1914 to 1945 . Economic warfare was never quite off the agenda of national policy makers during the interwar years. Conflicts over German reparations seriously affected monetary policy and trade relations, as well as international capital flows during the 1920s (Temin, 1989). To an even stronger degree, the economies of Europe were overshadowed by Germany's aggressive stance and war preparation in the 1930s.

With political intervention came the attempt to deepen the theoretical understanding of its effects. The interwar period saw the invention of macroeconomics as a separate subfield of economics. It soon extended from the new Keynesian theory of unemployment to public sector economics, balance of payment theory, and monetary economics. At the same time, rapid progress was made in welfare economics. Shaped by the traumatic experience of the interwar years, the economics generated in this period were sceptical about market forces, dismissive of the power of monetary and exchange rate policy, and highly optimistic about the power of the state to intervene in economic activity, be it through fiscal policy, financial repression, or a combination of the two. Again, the consequences were far-reaching, as this mindset shaped an 
interventionist approach to macroeconomic policy that prevailed far into the 1970s.

Given the highly pathological nature of our period of interest, there has never been a shortage of attempted economic interpretations. Explaining the Great Depression after 1929 has even come to be regarded as the "holy grail" of macroeconomic theory (Bernanke (2000). Given the complexity of the phenomenon and the multiplicity of rivalling explanations, any attempt at describing the business cycle of the period from 1914 to 1945 will necessarily have to be eclectic, walking a fine line between the single-mindedness needed to achieve analytical depth and the imprecision required for providing a tour d'horizon.

This chapter sets out to review Europe's macroeconomic performance between 1914 and 1945. It highlights key stylised facts and surveys some of the most prominent attempted explanations. Section 2 looks at a salient feature of this period, the highly persistent deviation of aggregate output per capita from its long term growth path after 1914. Inspection of these data suggests a business cycle chronology that holds for most of the countries for which we have data. Section 3 reviews monetary factors and highlights the instability of the nominal side of the economy in this period. Section 4 turns to social conflict as one driving force of the interwar business cycle, and looks at its consequences. These include the displacement of factor shares after World War I in key European countries, the shortening of the industrial workweek, as well as concomitant declines in income inequality. Section 5 documents the interplay between macroeconomic fluctuations and international trade and capital flows. Section 6 turns to foreign policy and international conflict as a possible driving force behind much of the interwar business cycle, and argues that its influence was pervasive. Section 7 concludes with remarks on the two dimensions of conflict that shaped the macroeconomic performance of the interwar period. Far from being a normal business 
cycle, economic fluctuations during the period between 1914 and 1945 were primarily driven by two forces that shaped events and profoundly altered the economic constitution of the European polity. One was social conflict and the institutions and labour market responses it created. The other was international conflict and the de-globalisation of the European economy it caused. Influenced by these two forces, the interwar period exhibited highly pathological macroeconomic performance, but was formative for the European economy during the second half of the $20^{\text {th }}$ century.

\section{Identifying the European business cycle}

The interwar period saw a succession of short-term business cycles, and at the same time was a long-term recession from historical productivity trends. This downward deviation began during the First World War and continued until the end of the Second World War. In the three decades after 1914, Europe's economy was in recession relative to trend during 14 years, and cumulatively lost thirty percent of its potential output (see Figure 1) ${ }^{1}$.

(Figure 1 about here)

Mirroring this development, the recovery from this depression, commonly referred to as the post-war Golden Age, lasted to the 1970 s. Why Europe's economic reconstruction from World War I remained

\footnotetext{
${ }^{1}$ Figure 1 is drawn under the assumption of $1.96 \%$ annual trend growth in GDP per capita, close to the $2 \%$ that are commonly regarded as trend growth in neoclassical growth theory. The slight downward deviation from the accepted stylized facts is caused by slightly lower trend growth in Britain. See on this Crafts and Mills (1996) and Crafts and Toniolo (1996), who argue for a break in British growth in the interwar period. Data in Figure 1. are calculated for the 14 European for which annual data are provided in Maddison (2003).
} 
incomplete, precipitating a Great Depression of thirty years, is one set of issues to be addressed in this chapter.

Embedded in Europe's long term depression were three short term recessions. The first lasted on average from 1914 to 1921 , the second from 1929 to 1932, and the third from 1940 to $1946^{2}$. With two of these recessions linked to the World Wars themselves, this would leave one true interwar recession.

Yet the aggregate European picture conceals major regional differences. Germany and most countries in Continental Europe were seriously affected by the WW1 recession, suffering output declines of up to $25 \%$ relative to pre-war levels. In contrast, Britain and Italy experienced a wartime boom. A major international recession in 1920/21 decreased national output in these two countries quite severely (by 20 and $25 \%$, respectively) but was hardly noticeable in most of Europe. During the rest of the 1920s, the economies of continental Europe recovered well, coming close to or even superseding the historical productivity trend (Figure 2). The two big exceptions to the rule are Germany and Britain, where recovery remained grossly incomplete: relative to a $2 \%$ productivity trend, neither country had recovered to much more than $80 \%$ of its potential by 1929 .

(Figure 2 about here)

The international recession of 1929 affected the whole of Europe, albeit in rather unequal measure. By the mid-1930s, the depression had reduced much of Europe to the low utilisation of their potential that had characterised Germany and Britain already in the 1920s. For most of

\footnotetext{
2 The evidence in Figure 1 seems robust to alternative assumptions about trends. Using e.g. a HP filter with the parameters suggested by Ravn and Uhlig (2002) leads to broadly the same chronology.
} 
these economies, the late 1930s were a time of relative stagnation or further deterioration, which accelerated in Southwest Europe with the Spanish Civil War (1936-39) and elsewhere with World War II (1939-45). Three major exceptions to this regularity stand out: Germany, Britain, and Scandinavia. In all three cases, recovery back towards the trend began in $1933^{3}$. This recovery was most complete in Scandinavia, which almost fully grew back to trend by 1939 . Germany experienced vigorous recovery to 1939 but was unable to continue on this path during World War II. Britain was hit less hard than Germany by the recession of 1929-32 and accordingly had a more muted recovery. During World War II, however, Britain's position relative to trend improved and quickly reached parity with Germany.

With a view to these distinct regional patterns, four groups of analytical issues suggest themselves. First, there is the question of what drove the recession of World War I, and why its regional effects on the economies of Europe differed so widely. A second set of questions relates to the speed and degree of economic recovery from World War I. A third group relates to the depression of the early 1930s, and to the question of why recovery remained isolated to a few places, while the rest of Europe experienced continued in depression through the 1930s. The fourth set of questions relates to the deepening recession during World War II. For all of these phenomena, a variety of explanations have been offered in the respective national and comparative literatures. While it is not possible here to review the many national cases in detail, certain common patterns do emerge. The following sections will consider the most prominent of them in turn.

\footnotetext{
${ }^{3}$ In the undetrended series, Britain's recovery begins already a year earlier. Relative to trend, however, this year was still one of recession.
} 


\section{Monetary factors in the interwar European business cycle}

While monetary calm reigned in most of Europe during the Classical Gold Standard of the late 19th century, Europe's monetary and financial systems emerged battered from World War I. All countries had suspended gold convertibility in 1914, and wartime inflation had pushed price levels up by 50 percent or more. After the war ended, inflation was still rampant in the weak democracies that had newly been established in Central Europe. In other countries where the political environment was more favourable, post-war monetary stabilisation met with the new phenomenon of downward rigid wages, itself partly a consequence of the newly introduced collective wage bargaining schemes. Deflation in these countries combined with rising unemployment and low rates of output growth or even outright recession, as in Italy or Britain. Monetary stabilisation in Europe took almost a full decade after the war, and was just completed when the recession of 1929 struck.

Hyperinflation was rife in Germany as well in Austria, Hungary, and Poland. The first two were the former Central Powers, while the latter two had regained their independence after the dissolution of the Habsburg monarchy and the reversal of the $18^{\text {th }}$ century partition of Poland between Russia, Prussia, and the Habsburgs. Inflationary war finance, deficient tax systems, new customs borders and the concomitant decline of trade, as well as political turmoil towards the end of World War I all contributed to monetary instability in these countries. By 1919 or 1920, price levels had already increased tenfold or more compared to 1914 (Figure 3a). As a consequence, the middle classes' savings in nominal assets had essentially lost their value, and the most of war debt had been annihilated. Yet in all of these countries, the transition to hyperinflation only came after inflation had performed its fundamental economic function of wiping out the war debt. One major factor contributing to this delayed outburst of post-war hyperinflation was the inability of the newly 
formed states to enforce effective taxation. Political and fiscal stabilisation in the hyperinflation countries of the 1920s indeed went hand in hand, and monetary stabilisation followed once order had been restored to public finances (see Sargent (1982) and Dornbusch (1987)). Austria and Hungary were the two economies that had been particularly hard hit by the disintegration of the Habsburg Empire. With international help and rigorous public spending cuts, they stabilised in 1922 and 1924, respectively. Germany stabilised in late 1923, after internal revolts had been crushed, an understanding with France on accepting mediation in the conflict over reparations had been reached, and after emergency legislation had been passed to restore order to the government budget. Poland's stabilisation was delayed by war with Russia, and later by trade conflict with Germany. Poland's first, abortive attempt to join the gold standard in 1924 was followed by successful stabilisation in 1926. In all cases, currency stabilisation proved successful, as Figure 3a bears out: price levels did not spiral out of control again until World War II or after ${ }^{4}$.

Britain as well as most of the neutral countries of World War I returned to gold at the pre-war parity, reversing wartime inflation. Like in the U.S., deflation from wartime price levels was substantial but failed to restore pre-war price levels. By the end of the 1920s, consumer prices in these countries were on the average still 50 percent higher than in 1914, well in line with the U.S. Again, stabilisation was successful, as in most of these countries, the price levels of 1925 were not surpassed again before World War II (see Figure 3b). Wartime inflation after 1940 broadly repeated the pattern of moderate inflation from World War I, with the important exception that no post-war deflation occurred in these countries after 1945.

\footnotetext{
${ }^{4}$ In the German case, the inflationary trauma was a major factor in avoiding currency devaluation in the 1930s, motivating policy makers to impose capital controls instead, see Borchardt (1984).
} 
A number of countries led by France went the middle way and allowed prices to increase seven- to tenfold during World War I, without experiencing post-war hyperinflation, and also without attempting to return to pre-war gold parities. During the interwar period, price levels in these countries fluctuated around the levels attained in the early 1920s. As a consequence, war-related debts issued in domestic currency as well as nominal savings lost substantial parts of their value. This group of economies proved markedly less resistant than the others to the recurrence of wartime inflation in World War II, as Figure 3c shows.

(Figure 3 about here)

The monetary policy choices of the various European countries after World War I have attracted much scholarly attention. Britain's decision to accept post-war deflation to prepare for the return (ultimately in 1925) to the pre-war parity has been criticised ever since Keynes warned against the consequences of deflating. Downward wage rigidities, he argued, would increase real wages and thus translate deflation into depression. ${ }^{5}$ This link between the recession of 1920/1 and deflation after World War I is nowadays widely accepted ${ }^{6}$. Indeed, countries that experienced inflation at the time were spared from this recession. ${ }^{7}$ On the other hand, the same countries had seen the trough of their respective deep recessions around 1918/19 (see Figure 2 above). In addition, postwar deflation gained momentum in Britain only after the depression had set in ${ }^{8}$, just as post-war inflation in continental Europe picked up speed

\footnotetext{
${ }^{5}$ On the discussions among experts before Britain's return to gold, still see Moggridge (1969).

${ }^{6}$ See, prominently, Eichengreen (1992b) and Feinstein, Temin and Toniolo (1997).

7 For Germany, this point has been made by Webb (1989) and Holtfrerich (1986).

8 This point has been made by Cole and Ohanian (2002) and earlier by Broadberry (1986).
} 
only after the recovery had begun. Whether post-war deflation was indeed the cause for recession thus continues to be an open issue.

At the same time, Keynes' argument went, a British return to gold parity after an insufficient degree of price deflation would increase the real exchange rate relative to those countries that did not deflate, or that stabilised after going through hyperinflations. Relative price levels in Europe did vary considerably after the return to gold in the late 1920s, and the evidence does indeed bear out some of this claim. Converting the price level data in Figure 3 above into real exchange rates suggests strong currency undervaluation relative to the pound for the hyperinflation countries (albeit far less so for Germany), see Figure 4a. Currencies that stabilised at the pre-war parity were on the whole quite close to purchasing power parity with the pound, with the Netherlands as the only exception of some importance, see Figure 4b. Currency stabilisation at less than the pre-war parity par did coincide with substantial undervaluation, as evidenced in Figure 4c.

(Figure 4 about here)

The undervaluation of the French Franc has attracted much scholarly attention, not the least because of the implicit accusation that France manipulated the Gold Standard for its own political ends. More recent scholarship has pointed to French domestic instability and inflation as a source of currency instability in the 1920s, see Prati (1991), Mouré (1991), and Sicsic (1993). Whatever the political motives, it is apparent that France was not an isolated phenomenon. In the Gold Standard of the late 1920s, violations of purchasing power parity were prevalent in countries that had stabilised at lower parities, and were not quickly corrected by market forces. 
On the whole, it appears that those countries that stabilised at new parities fared substantially better in terms of unemployment in the 1920s than the others. Figure 5 shows indices of unemployment $(1932=100)$ for the same country groups as before. The unemployment experience of the countries stabilising after hyperinflations was mixed, see Figure $5 \mathrm{a}$.

Countries that had gone through deflations to stabilise at pre-war parities often suffered protracted unemployment already in the 1920s (Figure 5b). In contrast, those stabilising at lower rates enjoyed near-full employment in the 1920s (Figure 5c).

(Figure 5 about here)

All countries of Europe were badly affected by the adverse shock than came with the international depression after 1929. However, the crisis affected the countries of Europe in unequal measure and at different times. As Figures 3 and 4 bear out, the crisis was not primarily a deflationary or real exchange rate shock: deflationary tendencies in the gold parity countries were well under way in the 1920s already and just accelerated again after 1929, while real exchange rate movements did not really matter until 1931/32. Figures 1 and 2 bear out a strong output shock after 1929, although the timing of this shock seems far from uniform. The unemployment data in Figure $5 c$ broadly confirm this: on the whole, the countries that stabilised below par in the 1920s were latecomers to the depression of the 1930s. Compared to their good performance in the 1920s, they were also harder hit by the depression, and for the most part took longer to recover in the 1930s.

To what extent the economic collapse after 1929 was driven by monetary policy is still debated. Monetarist orthodoxy has blamed the decline, as well as most of the depression as such, on contractionary monetary policy in the U.S. in the late 1920s, see Friedman and Schwartz 
(1963). Critics have pointed out that Europe, notably Germany, created its very own deflationary pressures (Temin, 1989). The credit-oriented view that prevails in most of the discussion today sees reduced U.S. capital exports as the proximate cause of monetary contraction in Europe, see Kindleberger (1973), Feinstein, Temin and Toniolo (1997). Clearly, fixed exchange rates and generally high capital mobility under the restored Gold Standard of the 1920s acted as a mechanism that quickly transmitted the shock through Europe, see Choudri and Kochin (1980) and Bernanke (1995). Central banks across Europe reacted to reserve losses by tightening monetary policy according to the rules of the game of the Gold Standard. Fiscal policy played its part by tightening public budgets and compensating for lost tax revenue with spending cuts. In a matter of two or three years, price levels across Europe decreased by up to a quarter.

Yet the seemingly obvious connection between deflation and unemployment is less than easy to find in the data. Research on the dynamic Phillips curve would suggest short-term trade-offs between inflation and unemployment that allow monetary policy to have effects until the natural rate of unemployment is restored, see Clarida, Gertler and Gali (1999). Yet while there was ample variation in both unemployment and inflation during the interwar period, no systematic pattern seems to emerge in the data, even if the 1920s and the 1930s are looked at separately. The picture emerging from Figure 6 is rather that the natural rate of unemployment moved quite independently of inflation, irrespectively of whether or not a country was on gold. ${ }^{9}$

(Figure 6 about here)

\footnotetext{
9 Much more rigorous analysis would be needed to substantiate this point further. However, standard econometric procedures confirm this conclusion. This is left as an exercise to the reader.
} 
Downward spiralling prices increased the pressure on the banking system, as well as on central banks' currency reserves, which became politically unbearable in 1931. In May of 1931, Austria faced a banking crisis, and a run on the central bank was only narrowly averted. ${ }^{10}$ In July, Germany partly suspended convertibility after a bank run, forcing her international short term creditors to roll over existing loans. ${ }^{11}$ Partly as a consequence of seeing her loans to Europe frozen, Britain was forced to abandon gold in September. This truly revolutionary step - Britain had always been on gold in peacetime since the 1720s - marked the effective end of the gold standard. ${ }^{12}$ Governments all across Europe soon scrambled to either let their currencies float or protect them behind a firewall of capital controls, often doing both and embarking on a run to competitive devaluation. The countries of Scandinavia had pegged their currencies to the Sterling. Many countries in continental Europe followed Germany in abandoning convertibility so that whatever parity they adhered to became a mere numéraire without much economic meaning. Only a small group of countries held out in a French-dominated Gold bloc, which collapsed in 1936.

There is general agreement that, just as the gold standard transmitted the recessionary impulses internationally, breaking the "Golden Fetters" (Eichengreen, 1992) contributed to recovery. Eichengreen and Sachs (1985) as well as Bernanke and James (1991) argued for a connection between the speed of recovery from the depression and the departure from gold. According to this consensus, those countries that maintained their commitment to the gold standard incurred overvaluation of their currencies, were forced to keep interest rates high, and paid for this with sluggish and delayed recoveries. Figure

\footnotetext{
10 See Schubert (1991).

See James (1985), James (1986), Schnabel (2004).

12 The literature on this is huge. For a discussion see Eichengreen (1992b).
} 
7a shows inflation and GDP growth in the 1930s for countries on and off gold separately. While there is a weak positive correlation in both cases, the countries off gold exhibit higher overall GDP growth as expected. Figure 7.b examines the correlation between a currency's overvaluation relative to the sterling and its GDP growth in the 1930s. Contrary to expectation, no correlation seems to emerge. Instead real exchange rates among the devaluating countries appear to cluster around two levels: parity to sterling and undervaluation around $70 \%$, without any clear-cut growth advantage for either group. This is a puzzle: while countries that devalued had higher growth in the 1930s, neither induced inflation nor changes to external competitiveness, exploiting incomplete exchange rate pass-through, suggest themselves as a reason. Wolf (2008) has argued that the decision to devalue was largely driven by other considerations, and may have been endogenous to both inflation and currency undervaluation. The evidence in Figure 7 would be consistent with that.

By the late 1930s, the process of abandoning the gold standard had come to a close. The main characteristic feature of the new currency system was the prevalence of bilateral exchange agreements that often subjected long lists of goods to quotas and an elaborate system of split exchange rates. While not the first country to move to such agreements, Germany became the centre of this system after 1933, and tried to exploit it for its economic war preparation. ${ }^{13}$

Monetary factors, being the most prominent interpretation of the interwar depression today, thus contribute to its explanation in varying measure. Deflationary monetary policy is still popular as an explanation of the recession of 1920/21 in the UK and the US. Yet, as we have seen, deflation without depression was widespread in Europe after World War I, casting some doubt on this explanation. In contrast, the role of fixed

\footnotetext{
${ }^{13}$ See Ellis (1941). A review of the literature is Ritschl (2001).
} 
exchange rates in spreading the depression after 1929 is undisputed. Countries that broke off the gold standard in the 1930s fared better than those which did not. Yet the mechanisms behind this appear to be less obvious than it seems.

\section{Social conflict and the European inter-war business cycle}

Before 1914, most economies of Europe resembled the model of the $19^{\text {th }}$ century market economy, with little or no welfare policy and no institutional role for trade unions. Also, most European societies still had large employment shares in agriculture, so that the task of providing insurance against old age or sickness was largely still borne by the family.

After World War I, many countries saw their social institutions and labour markets being reshaped very swiftly, and with far-reaching consequences. In the more advanced economies, the eight hour day became the norm in industry almost universally. Unionisation and the right to strike were now institutionalised or at last became common practice. ${ }^{14}$ This had the effect of altering the wage finding mechanism away from bilateral towards collective bargaining. In the wake of this institutional change, wage shares in national incomes went up markedly compared to the pre-war period. ${ }^{15}$

At the same time, the beginning of active welfare policy and the gradual introduction of unemployment insurance increased the replacement ratio, i.e. the level of welfare benefits relatives to the going wage. Some countries in Europe instead experimented with generous minimum wages, arguably with similarly adverse results.

All these factors - the increased bargaining power of unions, the rise in replacement ratios, the introduction of minimum wages - have

\footnotetext{
${ }^{14}$ See the comparative evidence on trade unions collected by Bain and Price (1980).

${ }^{15}$ See Broadberry and Ritschl (1995) for evidence on Britain and Germany.
} 
been held responsible for persistent unemployment and a slow pace of recovery in the early $1920 \mathrm{~s}^{16}$ Similar views have also been held for the persistence of the depression into the $1930 \mathrm{~s} .{ }^{17} \mathrm{~A}$ case in point is the prolabour policy of the Blum government in France beginning in $1934 .^{18}$ There is also the claim, now well accepted, that welfare policies and labour-friendly wage mediation by the state contributed to the economic demise of Germany's Weimar Republic. ${ }^{19}$

The expansion of the welfare state and the adoption of labourfriendly wage finding mechanisms in the early 1920s went hand in hand with major political convulsions in much of Europe. Everywhere, labour movements gained political influence and used it to promote the rights of organised labour, as well as universal suffrage and women's rights. In spite of attempts to find a compromise with organised labour during World War I, monarchies everywhere on the continent were toppled in revolutionary processes, with the exception of the Netherlands and Scandinavia, which had been neutral in the war and where transition to democracy was managed peacefully. Under threat from the extreme left, which had taken power in Russia (and briefly in Hungary and parts of Germany), right wing movements formed in many parts of Europe. These movements would share the revolutionary impetus of the left and appeal to similar strata of the population. Yet they typically combined populist welfare policies with aggressive economic nationalism. Over time, the weak democracies that formed in continental Europe after World War I

\footnotetext{
${ }^{16}$ The seminal contribution on the effects of unemployment insurance in Britain is Benjamin and Kochin (1979). Broadberry (1986) emphasised the effects of unionisation and the eight hour day on labour supply and wage rates.

${ }_{17}$ In the context of a stochastic growth model with labour market frictions, Cole and Ohanian (2002) again stress the rise in the replacement ratio, combined with workers' decreased sectoral and regional mobility, as a main factor steering the UK away from its long-run trend in the 1920s and 1930s.

${ }^{18}$ See Beaudry and Portier (2002), who employ a framework related to that of Cole and Ohanian.

${ }^{19}$ Borchardt (1991 [1982]). Fisher and Hornstein (2002) obtain similar conclusions in a stochastic growth framework.
} 
increasingly came to feel the pressure from revolutionaries on both the left and the right. Before World War II, most of these countries had succumbed to authoritarian rule from the right. These regimes used the revolutionary impetus from the early 1920s, copying the model of Italian fascism, but rescinded the rights of organised labour. Trade unions were dissolved and labour was put under state-controlled umbrella organisations. Labour force participation of women was again discouraged, and agriculture received special promotion at the expense of further industrialisation. Still, industrial wage shares did not come down to the levels of 1913 again; all dictatorships of continental Europe built their legitimacy on pro-labour pretensions, and mostly refrained from cracking down on the material gains that labour had received in the 1920s as strongly as on their political organisations.

Soviet labour policies took a radical departure from the Western European model in the 1920s. But not unlike the right-wing dictatorships that later emerged in Europe, it suffocated independent labour movements and their political representations, and instituted statecontrolled umbrella organisations in their place. The effects of these policies on the material well being of the industrial working class seem doubtful. Collectivisation of agriculture according to the same principles entailed human cost that arguably amounted to several million lives, see Davies and Wheatcroft (2004).

While the labour market paradigm is useful in explaining post-war turmoil as well as the weak recoveries of the 1920s and the 1930s, it appears somewhat less successful in explaining the universal recession of 1929-32. High wage policies that may have adversely affected unemployment were in force quite evenly across Europe, yet the depth and the persistence off the 1929-32 recession varied quite a lot. In addition, recovery back towards historical trends was strongest in 
Scandinavia, where stringent pro-labour market regulation was in effect in the 1930s, and in Germany, where quite the opposite was true.

\section{International Trade}

In most European countries, the pre-1914 period was generally a time of moderate tariffs, which were often levied more for fiscal reasons than in order to protect home markets. Economic warfare during 1914-18 reduced trade to minimal levels, notably through the Allied blockade and - to a lesser extent - through German submarine warfare and other counter-blockade measures. As a consequence, international trade was severely depressed in Central Europe at the end of the war, but far less so in Western Europe with its access to the Atlantic Ocean. This wartime difference in trade appears to explain to a large extent the different timing of the wartime recession in Continental and Western Europe, discussed above in Section $2 .^{20}$

Restoration of commercial trade after World War I was generally sluggish, owing to some extent to the German reparations conflict and the developing hyperinflations in Central Europe. Tariff conflicts between Germany on the one hand and Poland and France on the other further delayed the recovery of trade in the mid-1920s. In East Central Europe, trade was further inhibited by the erection of tariff barriers between the former parts of the Habsburg monarchy. In addition, post-revolutionary turmoil in Russia and the establishment of a state monopoly in foreign trade seriously damaged Central Europe's trade with Russia.

As a consequence, trade had not fully recovered to its 1913 levels by 1929 . The general decline in overall trade volumes was accompanied

${ }^{20}$ Ritschl (2005) documents a tight relationship between declining imports and decreasing output in Germany for World War I. Disruption of imports to the British war economy, although at times substantial, was far less in magnitude, see Broadberry and Howlett (2005). 
by changes in the country and commodity structure of trade. Deprived of many of her overseas assets, Britain struggled to maintain balance of payments equilibrium in the 1920s, and lost major export markets for its declining classical industries of the $19^{\text {th }}$ century. Germany developed massive import surpluses during the hyperinflation, a tendency that continued through the 1920s almost without interruption.

The beginning of the international depression quickly depressed trade volumes once again. Short of foreign credit inflows that had supported its trade deficits in the 1920s, Germany adopted a policy of drastic deflation, and generated high trade surpluses since 1930, thus transmitting a strong recessionary impulse throughout Europe. ${ }^{21}$ Worries about foreign exchange reserves spread in 1931 and led to the widespread adoption of bilateral trade and exchange agreements, thus effectively linking trade flows to capital controls. The protectionist Smoot/Hawley tariff of 1930 in the U.S., as well as the Commonwealth's Ottawa preferences of 1932, added to the protectionist impetus.

Germany's transition to tight capital controls and trade quotas in 1933 cemented the new trade regime. As a consequence, international trade in the 1930s failed to fully recover from the recession, and the degree of openness of Europe's economies fell to lower levels than ever since the mid- $19^{\text {th }}$ century (Table 1 ). At the same time, the imbalances on capital accounts that had characterised the 1920s almost disappeared. Achieving equilibrium on the balance of payments and the balance of trade simultaneously became a paramount economic policy goal in the 1930s, and was implemented through policy fiat rather than through market forces.

(Table 1 about here)

${ }^{21}$ See Ritschl (2002b), Ritschl (2003). 
The trade policies of the 1930s were not just motivated by financial concerns. Import substitution policies targeted sectors thought to be strategically important. Agricultural protectionism aimed to improve selfsufficiency in order to confront future wartime blockades. As a consequence, substantial resources were invested in building up industries in sectors ranging from steel to chemicals and textiles, thus diverting and substituting trade for the sake of war preparation. This also implied major redistribution of incomes to domestic agriculture and to the import substitution industries. This in turn had the effects of slowing down the relative decline of agricultural employment, and of channelling substantial parts of the pool of unemployed into the new, war related import substitution industries. In this way, Europe in the 1930s fell back into a state of mercantilism, forgoing the gains from trade for the sake of increased national self-sufficiency, a policy goal that was incompatible with market processes.

\section{Capital flows, international conflict and the European inter-war business cycle}

Between the 1860s and 1914, international politics had remarkably little influence on economic fluctuations in Europe. Europe's advanced countries did attempt to use capital exports and direct investment in the periphery of Europe to their strategic advantage. ${ }^{22}$ Yet, most of the economic rivalry between Europe's Great Powers found its outlet in colonial adventures. Closer to home, the prevailing doctrine was to refrain from using state interventionism in markets as a leverage to gain the upper hand in international rivalries. An exemplary case was the "commercialisation" of France's reparations to Germany after the war of

\footnotetext{
22 See Fishlow (1985), Davis and Huttenback (1986). For more recent debates, see Flandreau, Le Cacheux and Zumer (1998), Ferguson and Schularick (2006).
} 
$1870 / 1{ }^{23}$ France issued bonds on international markets, paid off the Germans, and thus transformed its political debt into a purely commercial one. Germany used parts of the proceeds to back its new currency, the mark, which it linked to Britain's gold standard rather than to the Frenchdominated bimetallic system. Still, discriminatory practices in monetary policy were mostly absent. An atmosphere prevailed in which money and financial markets were seen as a matter for experts, to be sheltered from political interference. Under the classical gold standard that originated in the 1870s, central bank cooperation continued even in times of heightened political tension between their governments, notably in the crises of 1907 and $1911 .{ }^{24}$

All this changed dramatically with World War I. Schemes for punitive reparations were drawn up on both sides during the war. Germany's ruthless financial exploitation of occupied Belgium served as a model for future financial warfare. Large scale territorial changes were envisaged, and policy proposals discussed in German government circles even suggested the ethnical cleansing of large swaths of Eastern Europe $^{25}$. Given such scenarios, the armistice of 1918 and the economic conditions attached to it look less radical than it might first seem.

Historians have long argued that the feud over German reparations and its twin, the inter-allied credits owed to the U.S. by France and Britain, overshadowed financial relations between 1919 and 1932. The interference of political matters at times seriously impaired the normal functioning of international capital markets, and undermined domestic stability in some of the core countries. The reparations bill of 1921 is held to have contributed to tax revolt, civil unrest, and the transition to hyperinflation in Germany, see Feldman (1993). German refusal to pay

\footnotetext{
${ }^{23}$ See White (2001).

${ }^{24}$ Representative of a large literature is Eichengreen (1992a).

25 The seminal work on Germany's long term war aims is Fischer (1967).
} 
reparations at the stipulated rates played a part in destabilising the French budget in the early 1920s, with consequences for the Franc that lasted throughout the decade. ${ }^{26}$ American-brokered stabilisation of Germany under the Dawes Plan of 1924 set capital flows between Germany and international markets in motion again. ${ }^{27}$ Yet, it provided no final settlement and left the future of the controversial inter-allied debts open. French refusal to serve these debts to the US unless these were fully securitised by future German reparations led to a US credit ban on France. This had the effect of cutting the French off the American market and motivated France's much-criticised policy of hoarding gold, which in turn contributed to destabilising the inter-war gold standard. ${ }^{28}$

Capital flows between the US and Europe during the second half of the 1920s were nevertheless substantial. Many of these credit flows were directed to Germany, which on balance absorbed the entire net capital exports form the U.S. during the second half of the $1920 \mathrm{~s} .{ }^{29}$ For a half a decade, Germany turned into the world's largest net capital importer, enabling the Germans to pay all reparations under the Dawes Plan on credit. $^{30}$

Historians have argued that the Germans abused the Dawes Plan to over-borrow in international markets; ${ }^{31}$ sovereign debt theory would predict they had every incentive to do so. ${ }^{32}$ As a result, Germany's foreign

\footnotetext{
${ }^{26}$ Schuker (1976b), Prati (1991), Hautcoeur and Sicsic (1999).

${ }^{27}$ Among other things, the Dawes Plan internationalised Germany's central bank, protected its new currency from reparation transfers, provided a major international loan, and designed a new reparation schedule that was quite favourable to the Germans. However, it provided no final settlement.

${ }^{28}$ See Schuker (1976a) on the political fallout of the Dawes Plan. A contemporary treatment of the interconnection between the two types of debt is Boyden (1928). On the political constraints of French currency policy at the time see Mouré (1991).

${ }^{29}$ See Ritschl (2002b).

${ }^{30}$ See Kindleberger (1973) for a discussion of this debt recycling mechanism.

31 See Link (1970), Schuker (1988).

${ }^{32}$ Ritschl (2002a).
} 
debt, including the present value of reparations, stood somewhere near 80 percent of GNP in 1929 when the international recession broke out.

Monetary and financial crisis management under the informal rules of central bank cooperation established in the $19^{\text {th }}$ century would have dictated swift and discreet support for the German currency once difficulties arose. Such cooperation as existed during the inter-war period clearly failed to provide these services. ${ }^{33}$ The attempted ersatz commercialisation of German reparations in the Dawes Plan had seemingly succeeded in decoupling international politics and financial relations for a while. With the much stricter Young Plan of 1929/30, the former link between the two was firmly re-established. Being essentially a payback scheme for inter-allied war credits, the Young Plan aligned French and British interests in shedding off their war debt with America's interest in avoiding default on these credits. At the same time, it implicitly - and, one could argue, belatedly - placed Germany under Allied financial control, and thus inextricably intertwined any future monetary rescue operations under the Gold Standard with the German debt and reparation problem. ${ }^{34}$

To de-politicise central bank cooperation under these circumstances, the Bank of International Settlements was created. However, classical-style, discreet central bank cooperation proved impossible when after two years of forced deflation and austerity, the German payments crisis broke out in $1931 .{ }^{35}$ Plans for financial assistance were quickly loaded with political issues, and soon it turned

\footnotetext{
33 This is a central theme in Eichengreen's (1992) account of the inter-war depression. On the wider theme of inter-war central bank cooperation, see Clarke (1976). A rather more critical perspective is Mouré (2002).

${ }^{34}$ Ritschl (2002a).

${ }^{35}$ On this and the following, see the detailed account of the German crisis given in James (1985), James (1986). Toniolo (2005) documents the attempts to implement cooperation at the nascent Bank of International Settlements in spite of political intervention from all sides.
} 
out that no debt relief was possible without addressing the deeper issues underlying the Young Plan. A temporary way out of the deadlock was only achieved after the US proposed a one-year moratorium on all political debt, thus finally accepting the link between reparations and inter-allied debt. The price for this political arrangement in lieu of central bank cooperation was the imposition of capital controls in July of 1931, and thus Germany's exit from the Gold Standard.

German debt problems and international conflict continued to plague financial markets through the mid-1930s. Negotiations over reparations were delayed to mid-1932, provoking further deflationary measures in both France and Germany. In the wake of the end to German reparations (in August 1932), France and Britain declared default on their inter-allied war debt owed to the US (in December 1932). Germany defaulted on increasing portions of her commercial debt and obtained rescheduling deals on others. By 1935, the average default rate was between 80 and 90 percent. ${ }^{36}$ As a consequence, international financial relations in Europe were channelled into a network of increasingly tight capital and exchange control agreements. ${ }^{37}$ Before World War II, trade and payments in large parts of Europe had become a matter of politics and bureaucratic interference, creating a new, extreme version of mercantilism whose principal aim was to utilise trade as a weapon in international conflict.

\section{Conclusions}

The inter-war period witnessed a long-term downward deviation from Europe's output and income growth trends, a truly Great Depression that lasted from 1914 to 1945 and that has no comparison in the $19^{\text {th }}$

\footnotetext{
${ }^{36}$ Klug (1993).

37 See Einzig (1934), Child (1958).
} 
century. In it were embedded three severe recessions, each of which would probably qualify for being the deepest European recession since the Industrial Revolution, had it not been for the respective subsequent, even deeper one. This chapter surveyed some of the most prominent interpretations of these recessions. It has argued that this highly pathological period of European economic history cannot be analysed separately from two dimensions of conflict that ravaged Europe at the time. One is international conflict, represented by Germany's two wars against its neighbouring countries. The other is social conflict, connected mainly to the increasing role of labour movements and the concomitant changes in the distribution of income, but also to the first spread of civil rights and the changing role of women. Both dimensions of conflict strongly impacted on business cycle outcomes in the inter-war period.

Social conflict is one key variable that may have steered the economies of Europe away from their previous long-term growth path: unionisation, the eight hour day, and the expansion of welfare benefits all changed the balance of bargaining power in labour markets, increased wage shares and lowered profit margins. Social conflict also was a key factor in the rise of authoritarian regimes all across continental Europe, which tried to reverse the results of the 1920s by forcing economic growth at the expense of living standards - usually achieving the latter but not necessarily the former policy goal.

International conflict was paramount in the war-related recessions of 1914-1918 and again 1940-45. But it also played a decisive part in the failed attempts to stabilise the European economies during the proper inter-war years. This chapter has argued that continuing conflict over Germany's reparations seriously impaired the functioning of international financial markets in the interwar period, and also prevented central bank cooperation from defusing the crisis of the Gold Standard in 1931. The German debt default that began to unfold in the spring of 1931 turned a 
serious but potentially manageable crisis of the European interwar monetary system into a catastrophe with long term consequences. Under the pathological political conditions prevailing in Europe during the interwar period, it is hard to see how a more robust international financial architecture could have been designed that would have produced significantly better outcomes. 
Figure 1: Europe's Great Depression and Recovery, 1913-1973: Western European GDP per Capita Relative to $1.95 \%$ Growth Trend

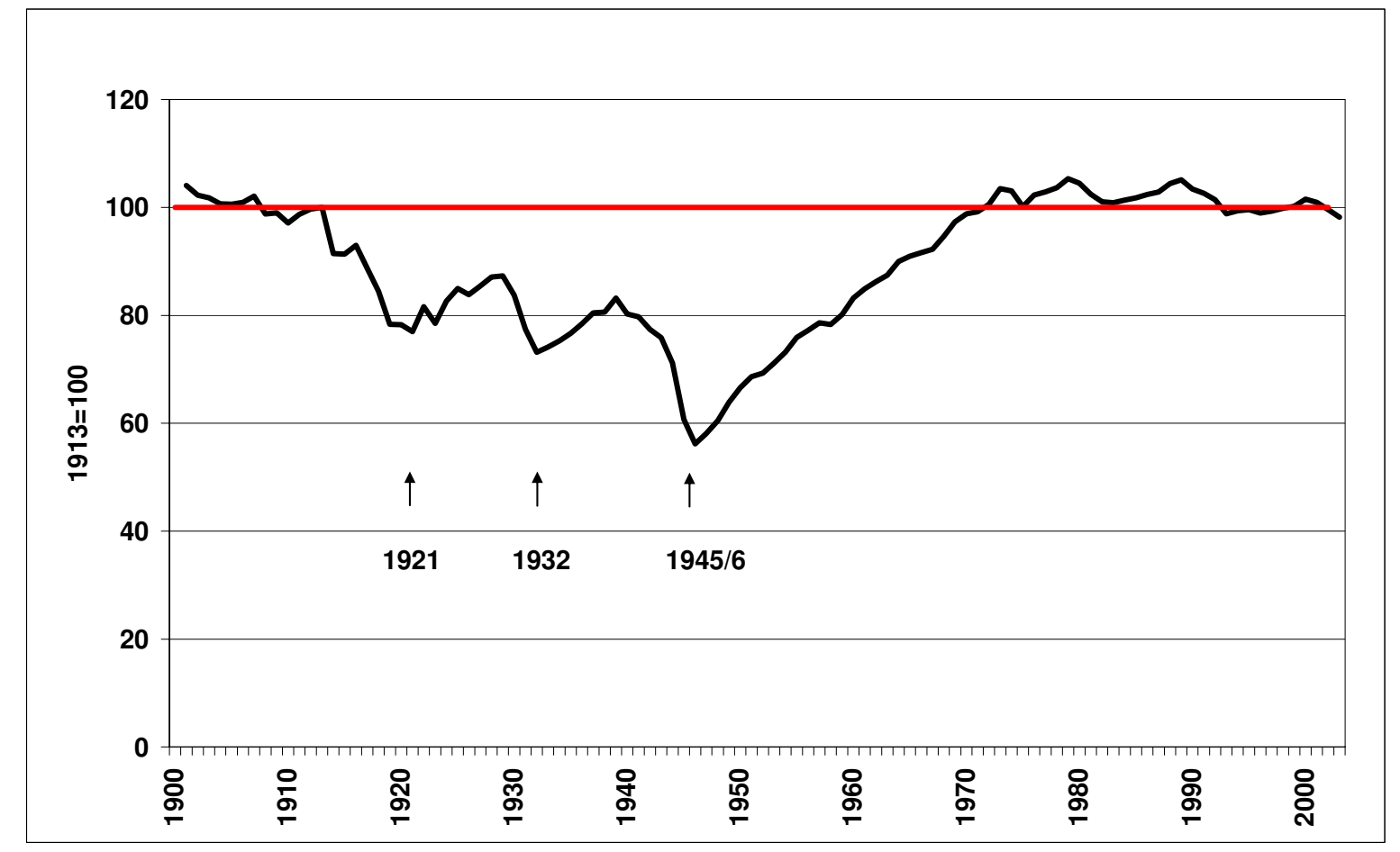

Source: Calculated from data in Maddison (2003) 
Figure 2: GDP per Capita Relative to $2 \%$ Growth Trend (1913=100)
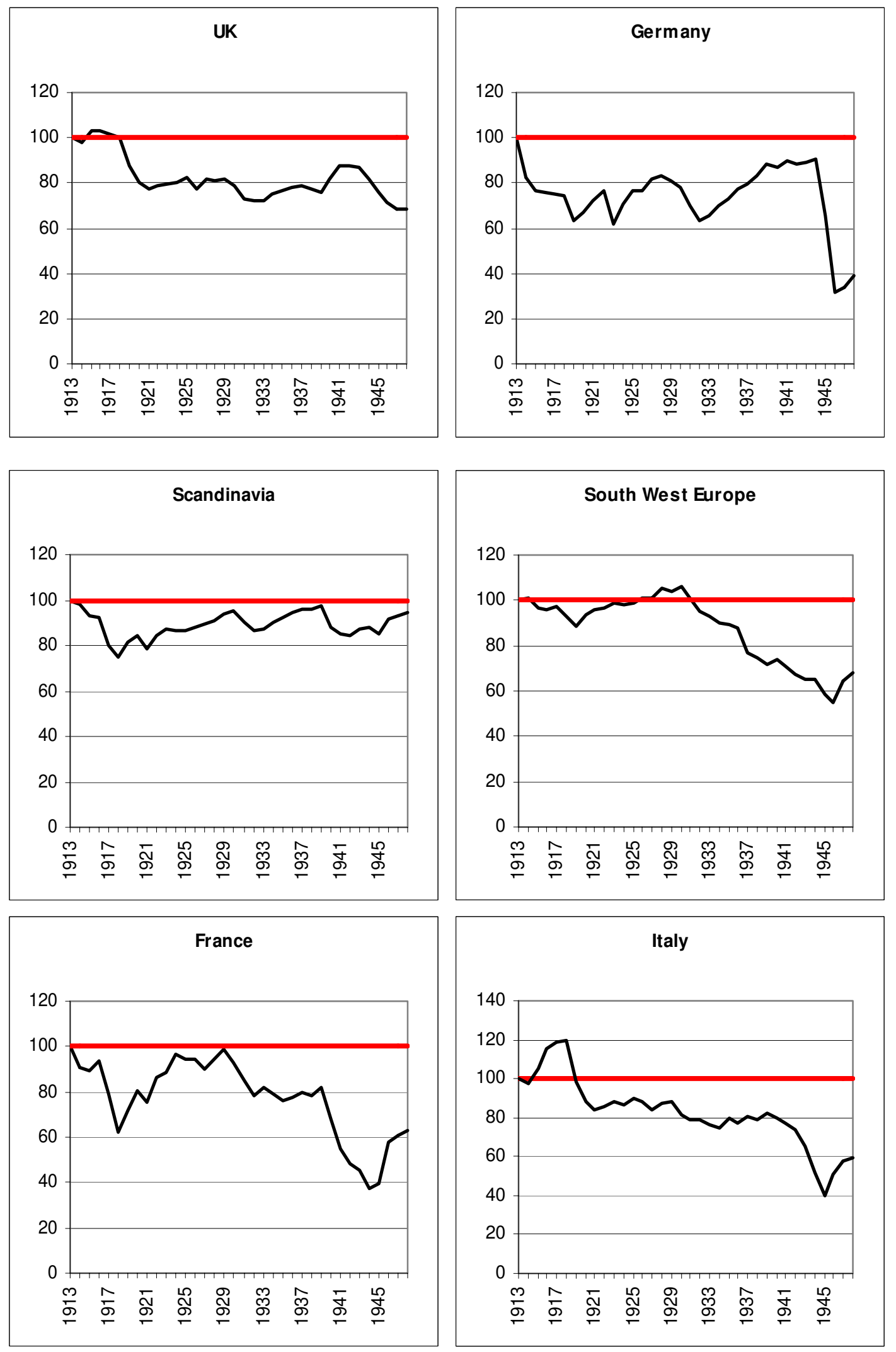

Source: Calculated from data in Maddison (2003) 
Figure 3: Postwar inflation, stabilisation, and inflation recurrence in Europe

a) Stabilising at pre-war parity after hyperinflation in the 1920s

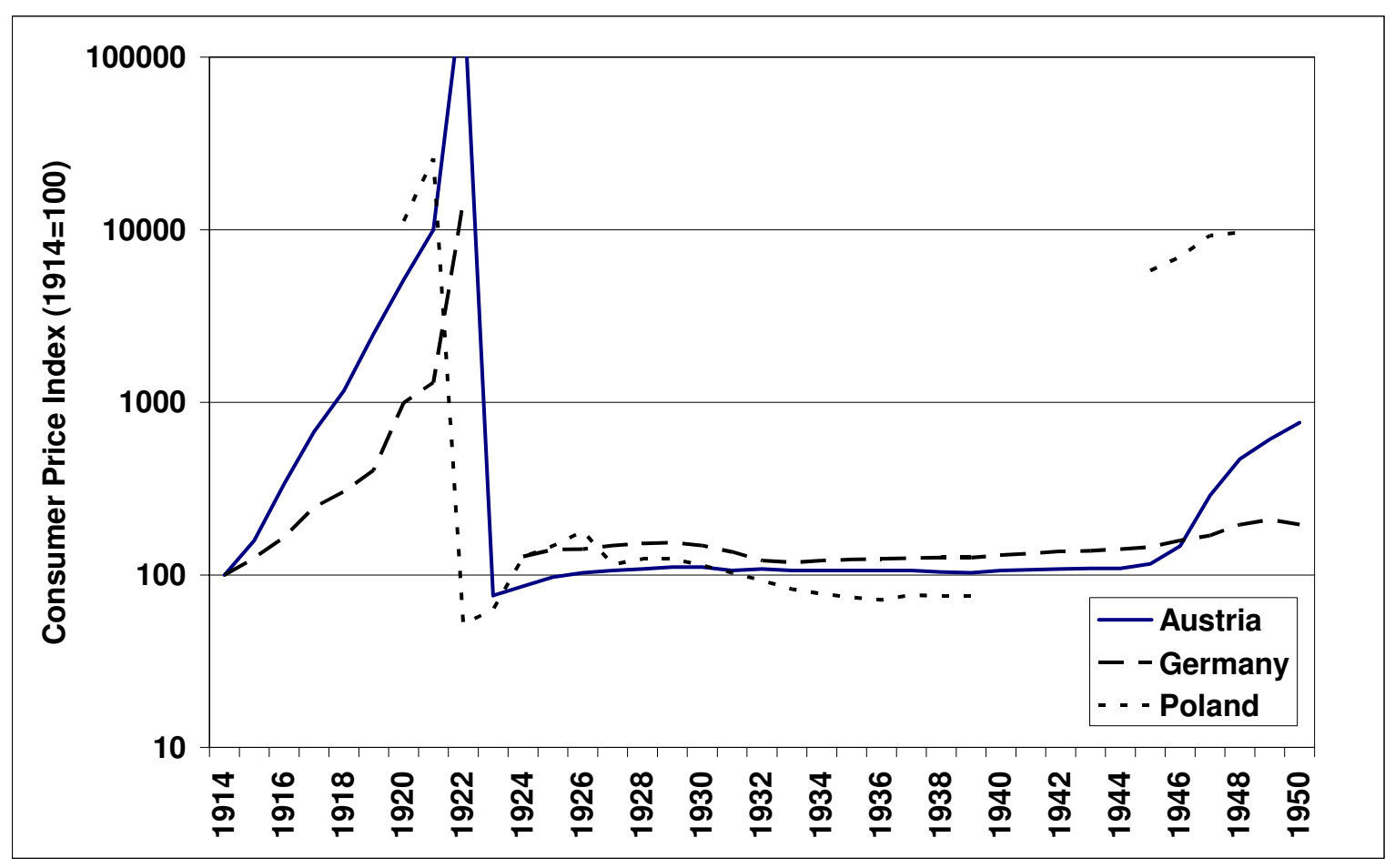

b) Stabilising at pre-war parity after deflation in the 1920s

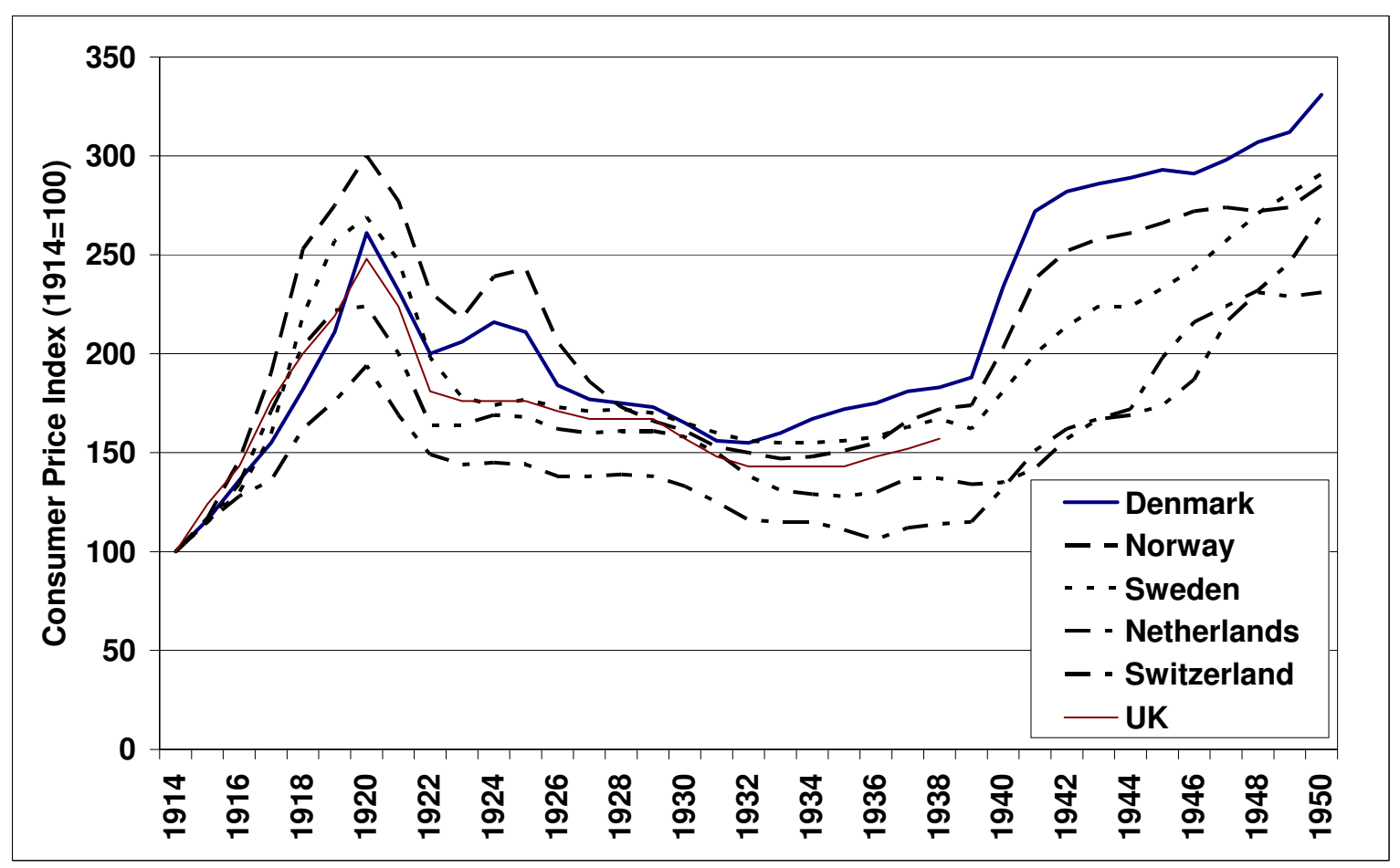




\section{c) Stabilising at new parity in the 1920s}

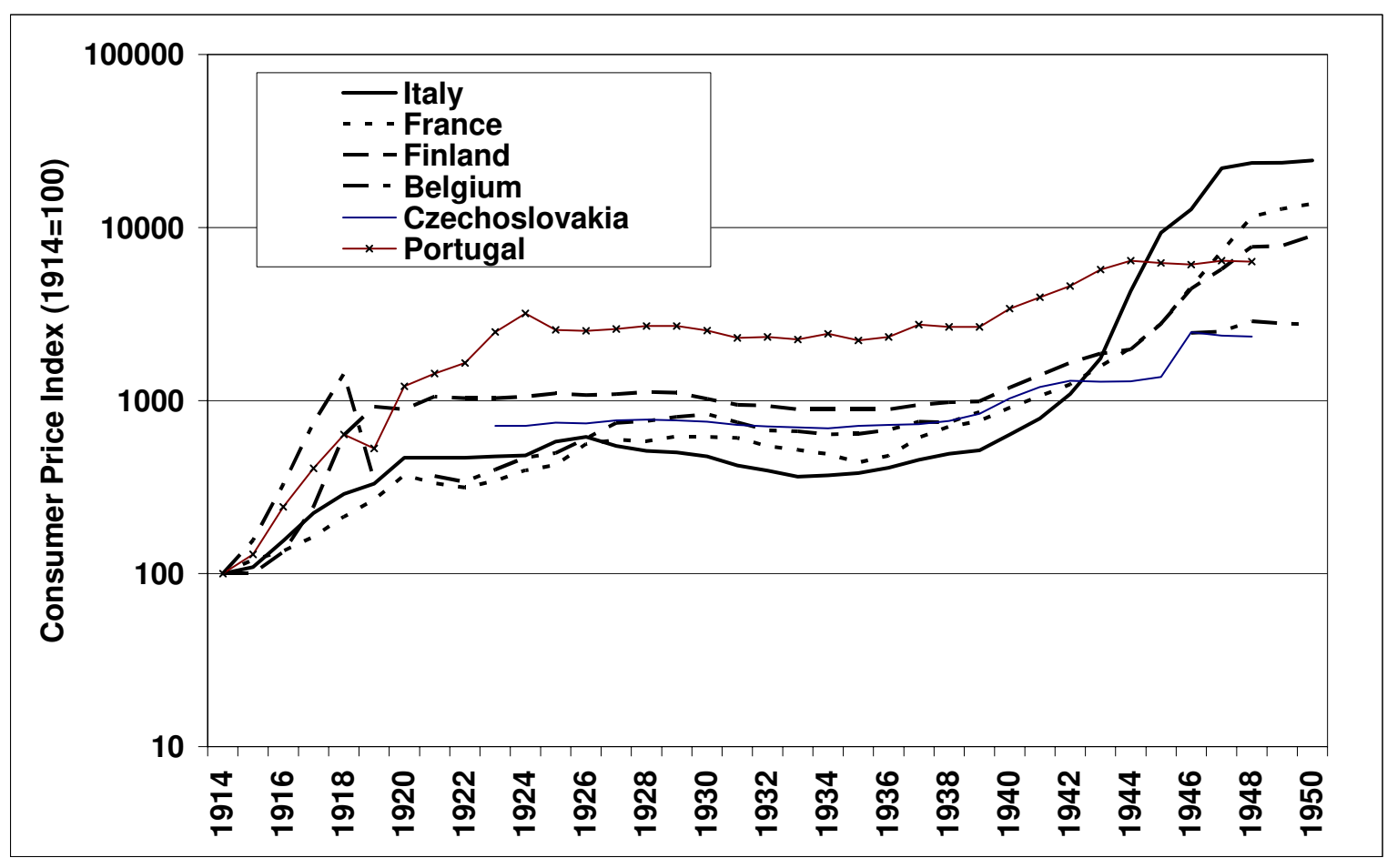

Source: Calculated from data in League of Nations (1931), League of Nations (1940), Mitchell (2003), Lains (2003) 
Figure 4: Real Exchange Rates $(U K=100)$

a) Stabilising at pre-war parity after hyperinflation in the $1920 \mathrm{~s}$

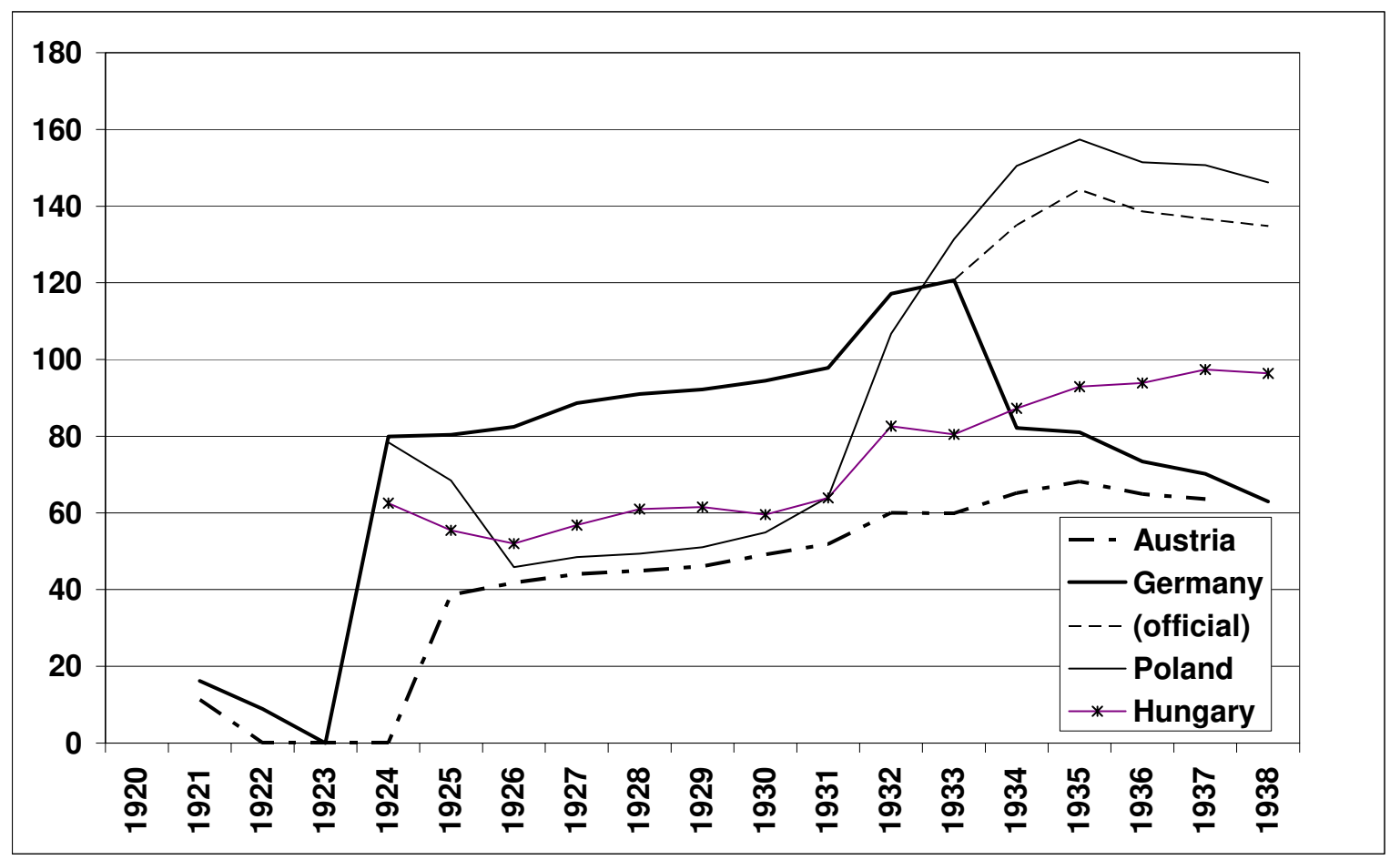

b) Stabilising at pre-war parity after deflation in the $1920 \mathrm{~s}$

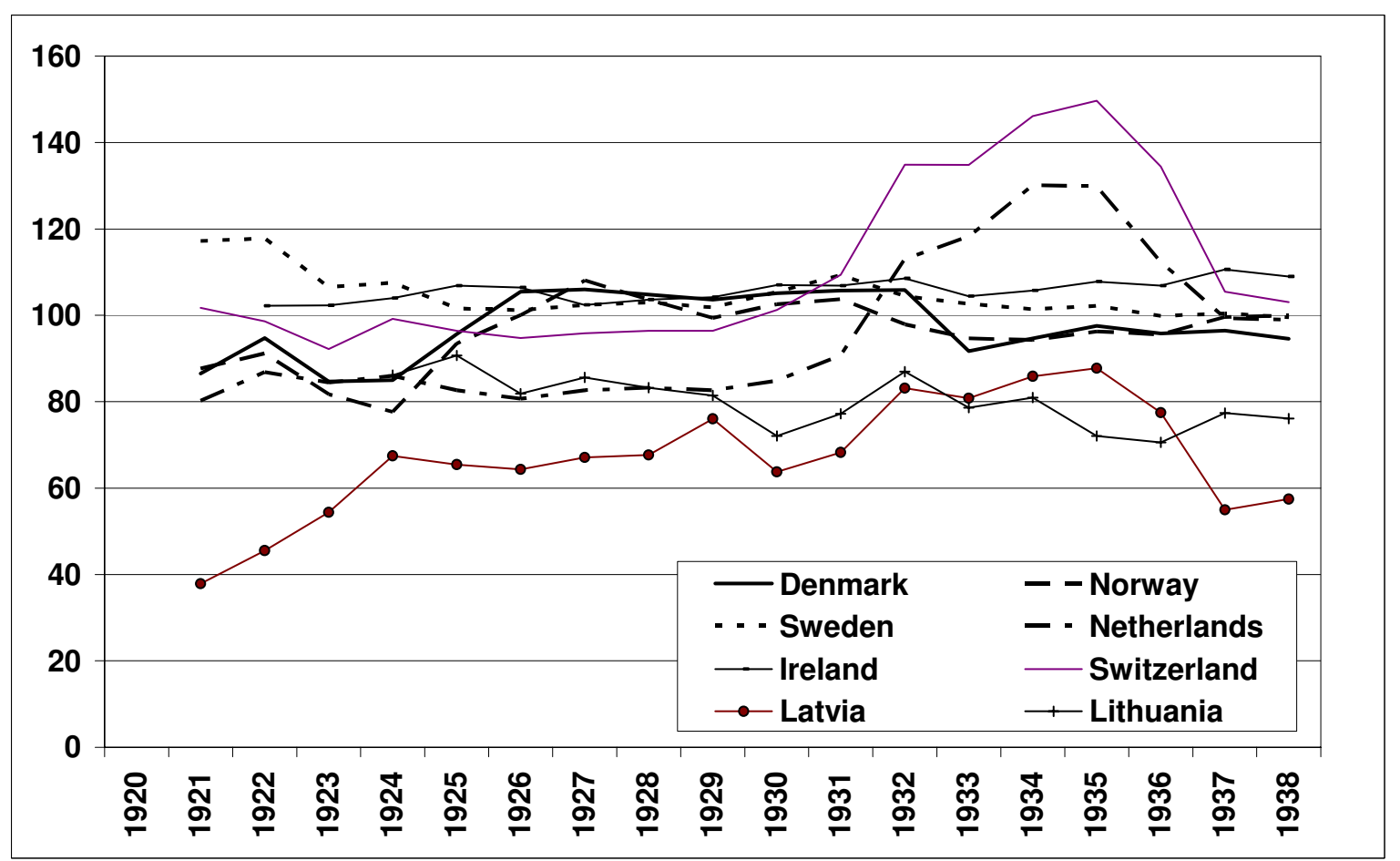


c) Stabilising at new parity in the $1920 \mathrm{~s}$

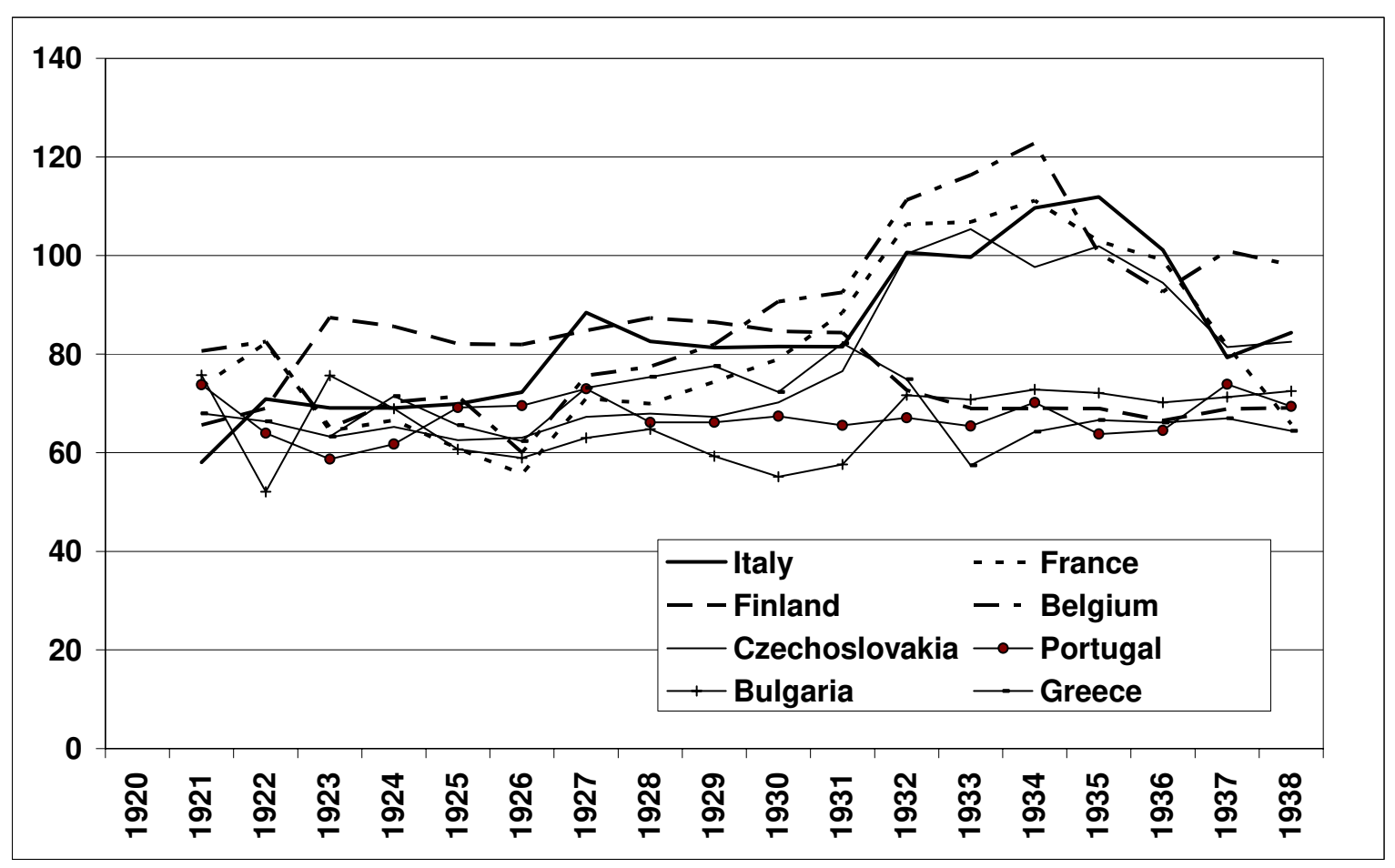

Source: Calculated from data in League of Nations (1931), League of Nations (1940), Mitchell (2003), Lains (2003) 
Figure 5: Unemployment

a) Stabilising at pre-war parity after hyperinflation in the $1920 \mathrm{~s}$

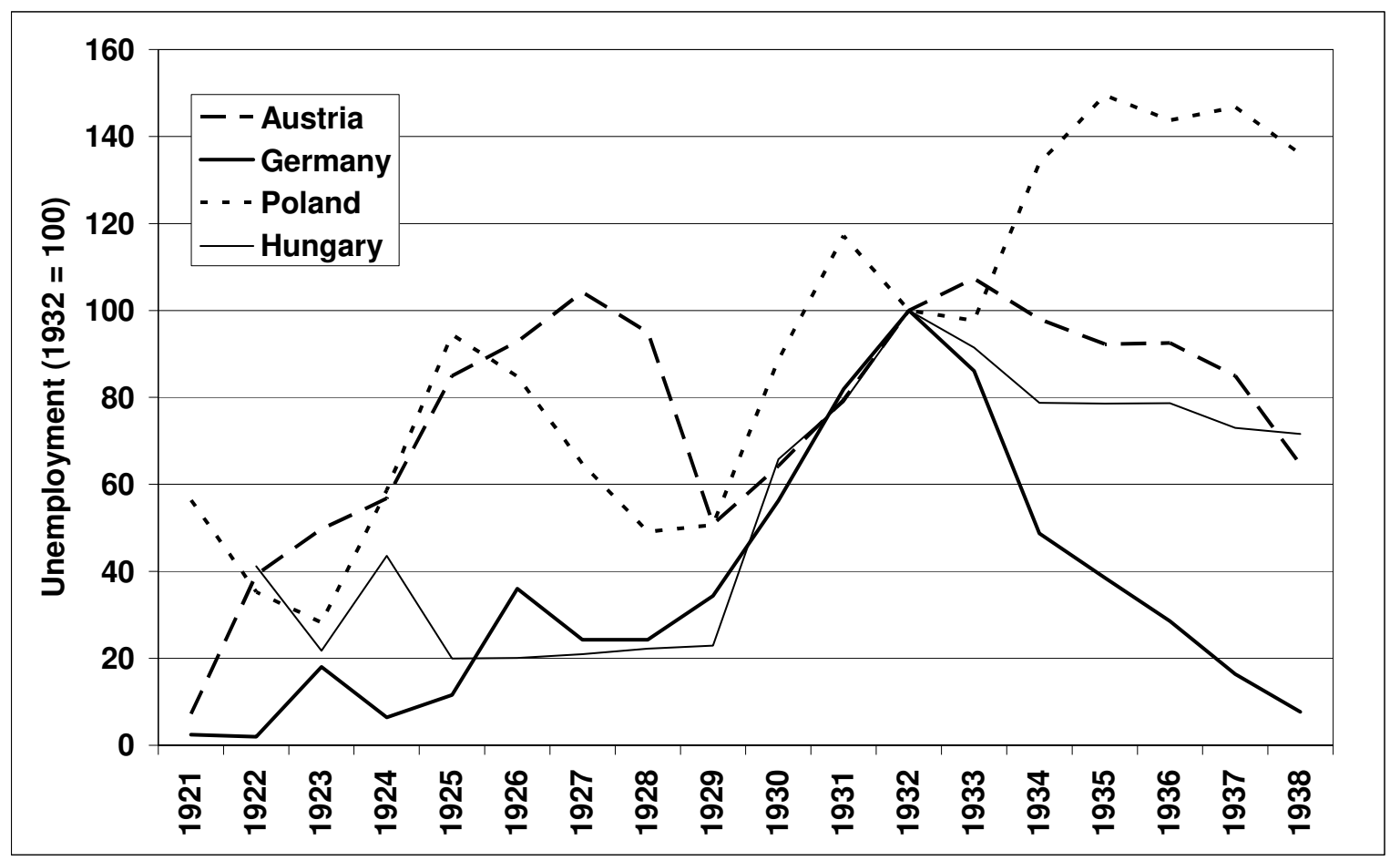

b) Stabilising at pre-war parity after deflation in the 1920s

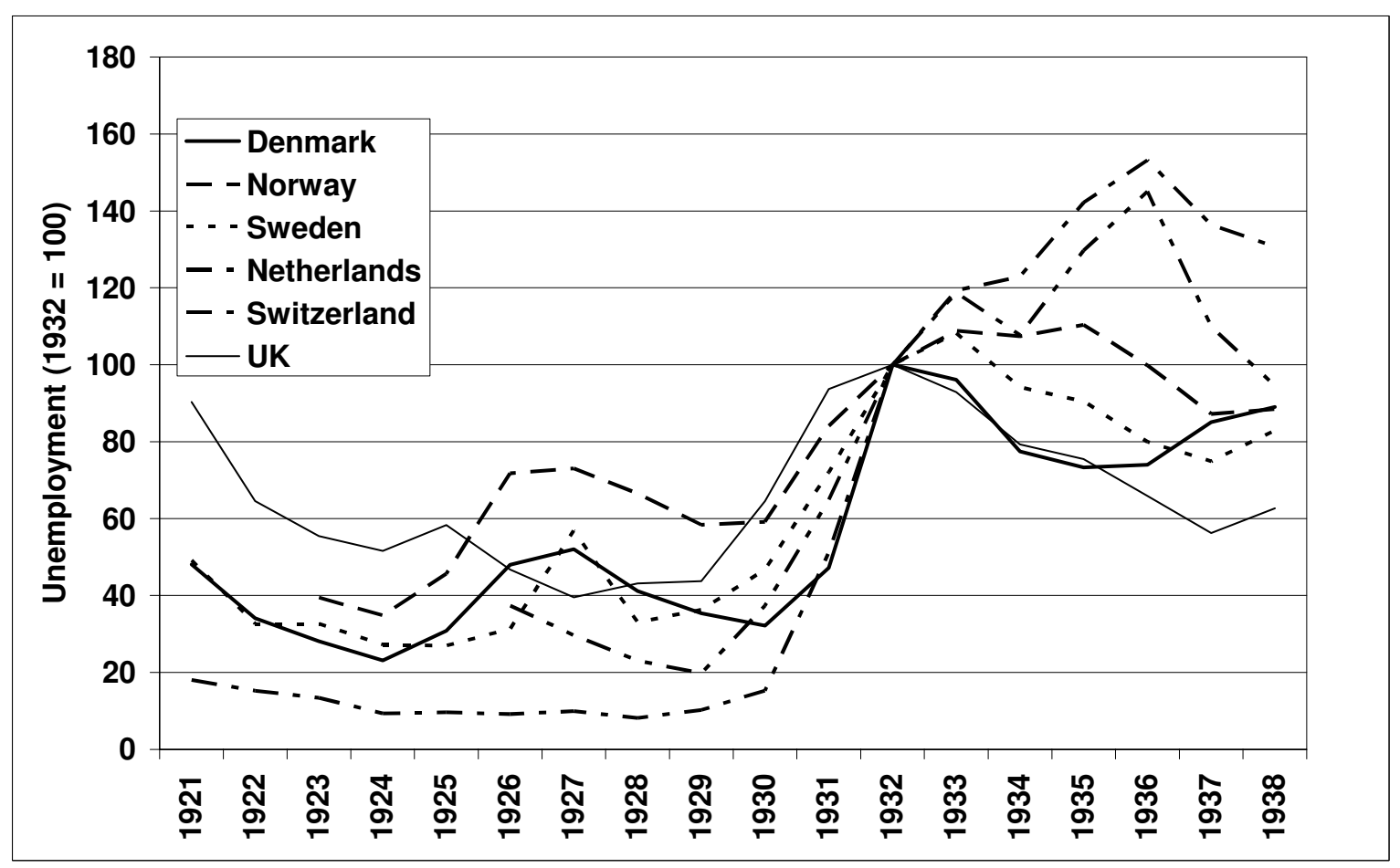


c) Stabilising at new parity in the $1920 \mathrm{~s}$

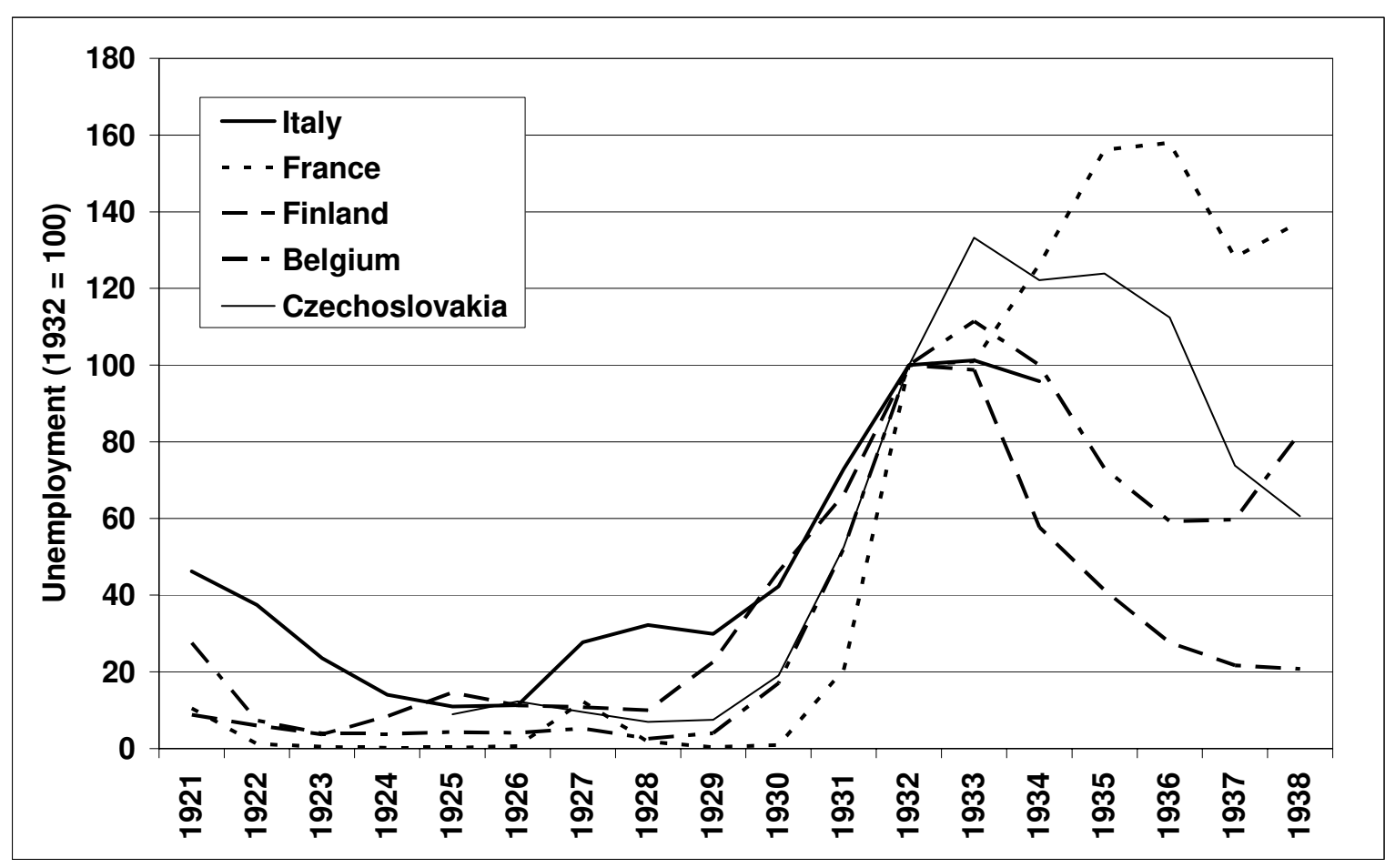

Source: Calculated from data in League of Nations (1931), League of Nations (1940). 
Figure 6: The Inflation/Unemployment Trade-Off
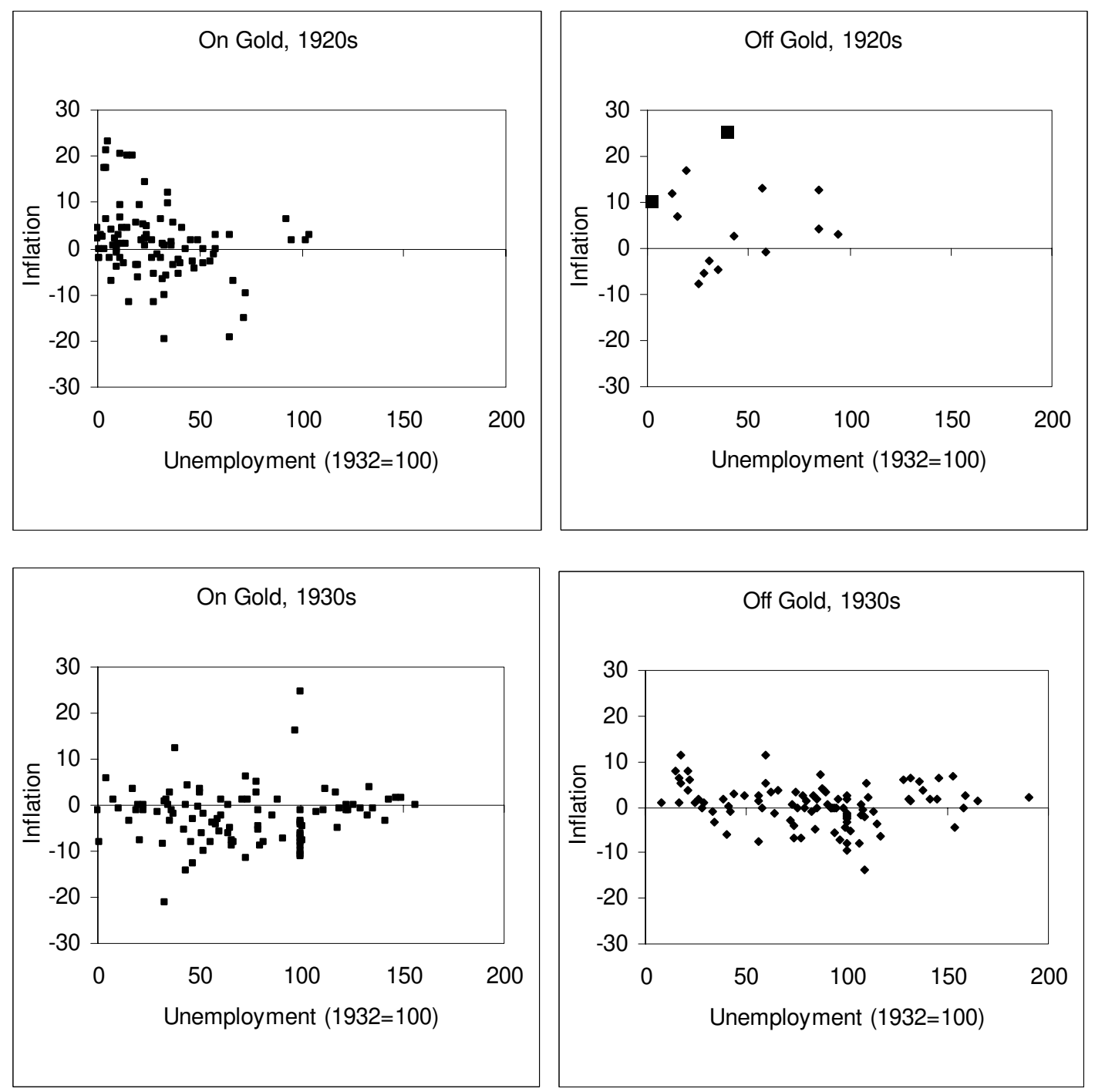

Source: See previous figures. Large boxes in 1920s: inflation is $y \times 10^{3}$. 
Figure 7: Devaluation and Economic Recovery in the 1930s

a) Inflation and Growth
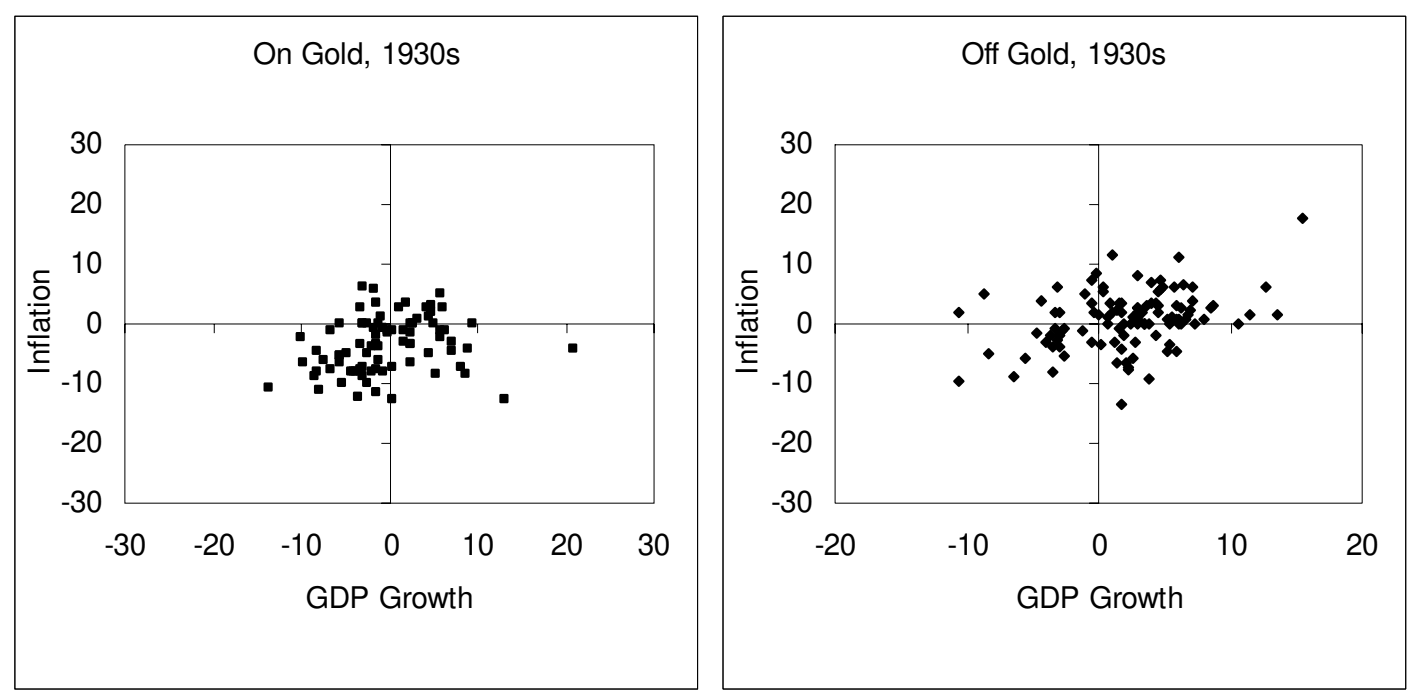

b) Real Exchange Rates and Growth
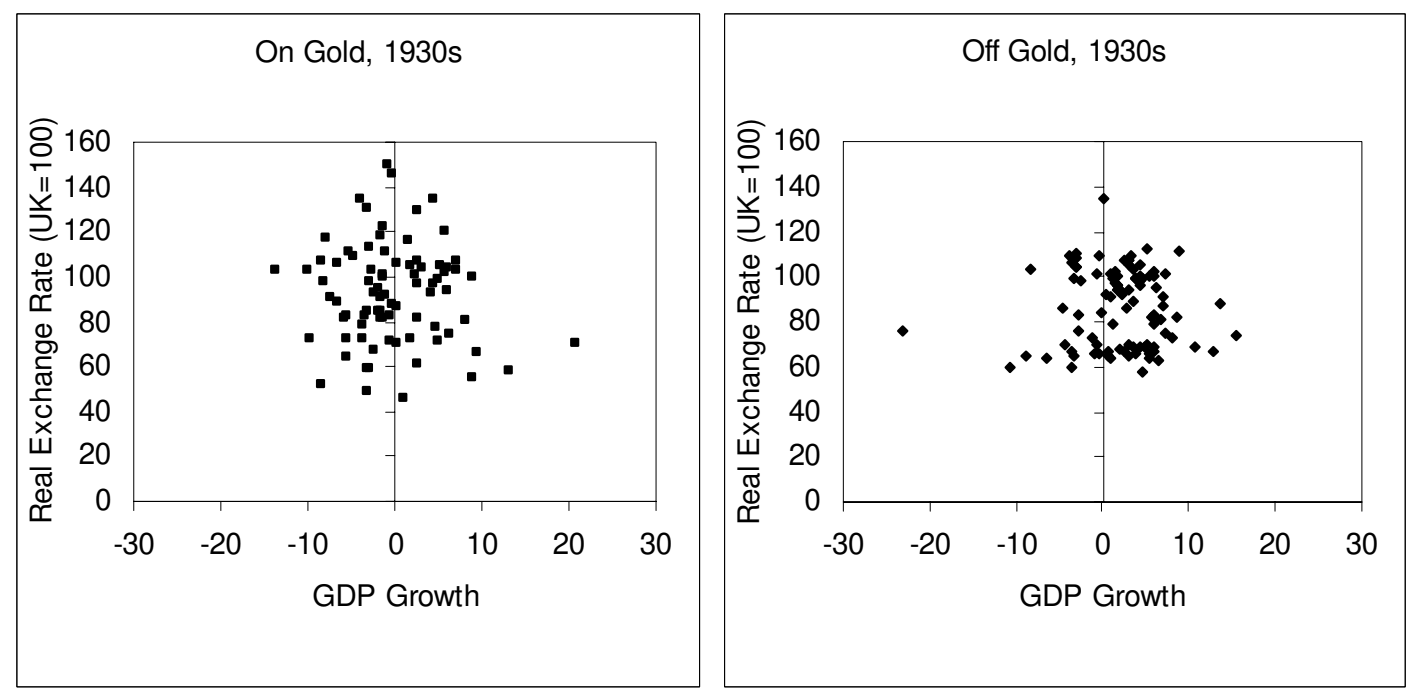

Source: see previous figures. 
Table 1: Regional Distribution of World Trade, 1913-1937 (Exports, mill. 1990 U.S. dollars)

\begin{tabular}{llrlrlr} 
& 1913 & & 1928 & \multicolumn{2}{c}{1937} \\
& & & & & \\
(in \%) & & & (in \%) & \\
$\begin{array}{l}\text { Europe } \\
\text { (including Russia) }\end{array}$ & 58.9 & 139198 & 48.0 & 160516 & 47.0 & 152284 \\
$\begin{array}{l}\text { North America } \\
\text { (Canada and US) }\end{array}$ & 14.8 & 34977 & 19.8 & 66213 & 17.1 & 55406 \\
Latin America & 8.3 & 19615 & 9.8 & 32772 & 10.2 & 33049 \\
Asia & 11.8 & 27887 & 15.5 & 51833 & 16.9 & 54758 \\
Africa & 3.7 & 8744 & 4.0 & 13376 & 5.3 & 17172 \\
Oceania & 2.5 & 5908 & 2.9 & 9698 & 3.5 & 11340 \\
& 100.0 & 236330 & 100.0 & 334408 & 100.0 & 324009
\end{tabular}

Source: Our calculations using data from Kenwood and Lougheed (1992) and Maddison (1995). 
References:

Bain, G.S. and R. Price (1980), Profiles of Union Growth: A Comparative Statistical Portrait of Eight Industrial Countries, Oxford: Blackwell. Beaudry, Paul and Franck Portier (2002), "The French Depression in the 1930s," Review of Economic Dynamics 5, 73-99.

Benjamin, D. and L. Kochin (1979), "Searching for an Explanation of Unemployment in Inter-war Britain," Journal of Political Economy 87, 441-478.

Bernanke, Ben (1995), "The Macroeconomics of the Great Depression: A Comparative Approach," Journal of Money, Credit and Banking 27, 1-28.

Bernanke, Ben (2000), Essays on the Great Depression, Princeton:

Princeton University Press.

Borchardt, Knut (1984), "Could and Should Germany Have Followed

Britain in Leaving the Gold Standard?," Journal of European

Economic History 13, 471-498.

Borchardt, Knut (1991 [1982]), Perspectives on Modern German

Economic History and Policy, Cambridge: Cambridge University Press.

Boyden, Roland (1928), "Relation between Reparations and the interallied Debts," Proceedings of the Academy of Political Science in the City of New York 12 (5), 21-28.

Broadberry, Stephen (1986), "Aggregate Supply in Interwar Britain," Economic Journal 96, 467-481.

Broadberry, Stephen and Peter Howlett (2005), The United Kingdom

During World War I: Business as Usual?, in: Stephen Broadberry and Mark Harrison, eds., The Economics of World War I, Cambridge: Cambridge University Press, 206-234. 
Broadberry, Stephen and Albrecht Ritschl (1995), "Real Wages,

Productivity, and Unemployment in Britain and Germany during the 1920s," Explorations in Economic History 32, 327-349.

Child, Frank (1958), The Theory and Practice of Exchange Control in Germany, The Hague.

Choudri, Ehsan and Levis Kochin (1980), "The Exchange Rate and the International Transmission of Business Cycle Disturbances: some Evidence from the Great Depression: ," Journal of Money, Credit, and Banking 12, 565-574.

Clarida, Richard, Mark Gertler and Jordi Gali (1999), "The Science of Monetary Policy," Journal of Ecoomic Literature.

Clarke, Stephen (1976), Central Bank Cooperation 1924-31, New York: Federal Reserve Bank of New York.

Cole, Harold and Lee Ohanian (2002), "The Great U.K. Depression: A Puzzle and Possible Resolution," Review of Economic Dynamics 5 (1), 19-44.

Crafts, Nicholas and Terence Mills (1996), Europe's Golden Age: An Econometric Investigation, in: Bart van Ark and Nicholas Crafts, ed. Quantitative Aspects of Postwar Economic Growth, Cambridge: Cambridge University Press.

Crafts, Nicholas and Gianni Toniolo (1996), Postwar Growth: An Overview, in: Nicholas Crafts and Gianni Toniolo, eds., Economic Growth in Europe since 1945, Cambridge: Cambridge University Press, 1-37.

Davies, Robert William and Stephen Wheatcroft (2004), Years of Hunger. Soviet Agriculture, 1931-1933, London: Palgrave Macmillan.

Davis, Lance and Robert Huttenback (1986), Mammon and the Pursuit of Empire. The Political Economy of British Imperialism, 1860-1912, Cambridge et.al.: Cambridge University Press. 
Dornbusch, Rüdiger (1987), Lessons from the German Inflation

Experience of the 1920s, in: R. u. a. Dornbusch, ed.

Macroeconomics and Finance: Essays in Honor of Franco

Modigliani, Cambridge: Cambridge University Press, 337-366.

Eichengreen, Barry (1992a), "Conducting the International Orchestra:

Bank of England Leadership Under the Classical Gold Standard,

1880-1913," Journal of International Money and Finance (6), 5-29.

Eichengreen, Barry (1992b), Golden Fetters. The Gold Standard and the

Great Depression 1919-1939, Oxford: Oxford University Press.

Eichengreen, Barry and Jeffrey Sachs (1985), "Exchange Rates and

Economic Recovery in the 1930s," Journal of Economic History 45, 925-946.

Einzig, Paul (1934), Germany's Default: The Economics of Hitlerism,

London: Macmillan.

Ellis, Howard (1941), Exchange Control in Central Europe, Cambridge.

Feinstein, Charles H., Peter Temin and Gianni Toniolo (1997), The

European Economy Between the Wars, Oxford.

Feldman, Gerald (1993), The Great Disorder. Politics, Economics, and

Society in the German Inflation, 1914-1924, Oxford: Oxford University Press.

Ferguson, Niall and Moritz Schularick (2006), "The Empire Effect: The

Deterrminants of Coountry Risk in the Age of Globalization, 1880-

1913," Journal of Economic History 66 (283-312).

Fischer, Fritz (1967), Germany's Aims In the First World War, London:

Chatto \& Windus.

Fisher, Jonas and Andreas Hornstein (2002), "The Role of Real Wages,

Productivity, and Fiscal Policy in Germany's Great Depression

1928-1937," Review of Economic Dynamics 5 (1), 100-127. 
Fishlow, Albert (1985), "Lessons from the Past: Capital Markets During the 19th Century and the Interwar Period," International Organization 39, 383-439.

Flandreau, Marc, Jacques Le Cacheux and Frédéric Zumer (1998), "Stability without a Pact? Lessons from the Gold Standard 18801913," Economic Policy, 117-162.

Friedman, Milton and Anna Schwartz (1963), A Monetary History of the United States 1867-1960, Princeton: Princeton University Press. Hautcoeur, Pierre-Cyrille and Pierre Sicsic (1999), "Threat of a Capital Levy, Expected Devaluation, and Interest Rates in France During the Interwar Period," European Review of Economic History 3, 2556.

Holtfrerich, Carl-Ludwig (1986), The German Inflation, New York: de Gruyter.

James, Harold (1985), The Reichsbank and Public Finance in Germany, 1924-1933: A Study of the Politics of Economics during the Great Depression, Frankfurt am Main: Knapp.

James, Harold (1986), The German Slump: Politics and Economics, 1924-1936, Oxford: Clarendon Press.

Kenwood, A and A Lougheed (1992), The Growth of the International Economy, 1820-1990, London: Routledge.

Kindleberger, Charles P. (1973), The World in Depression, 1929-1939, Berkeley: University of California Press.

Klug, Adam (1993), The German Buybacks 1932-1939: A Cure for Overhang?, Princeton: Princeton University Press.

Lains, Pedro (2003), Os Progressos do Atraso. Uma Nova História Económica de Portugal, 1842-1992, Lisbon: Imprensa de Ciências Sociais.

League of Nations (1931), Statistical Yearbook of the League of Nations 1931/32, Geneva: League of Nations. 
League of Nations (1940), Statistical Yearbook of the League of Nations 1939/40, Geneva: League of Nations.

Link, W. (1970), Die amerikanische Stabilisierungspolitik in Deutschland 1921-32, Düsseldorf: Droste.

Maddison, Angus (1995), Monitoring the World Economy, 1820-1990,

Paris: OECD.

Maddison, Angus (2003), The World Economy: Historical Statistics, Paris: OECD.

Mitchell, Brian (2003), European Historical Statistics, New York: Stockton. Moggridge, D. (1969), The Return to Gold 1925:the Formulation of

Economic Policy and its Critics, Cambridge: Cambridge University Press.

Mouré, Kenneth (1991), Managing the Franc Poincaré: Economic Understanding and Political Constraints in French Monetary Policy, New York: Cambridge University Press.

Mouré, Kenneth (2002), The Gold Standard Illusion: France, the Bank of France, and the International Gold Standard 1914-1939, New York: Oxford University Press.

Prati, A. (1991), "Poincare's Stabilization: Stopping a Run on Government Debt," Journal of Monetary Economics 27, 231-239.

Ravn, Morten and Harald Uhlig (2002), "On Adjusting the HP-Filter for the Frequency of Observations," Review of Economics and Statistics 84 (2), 371-376.

Ritschl, Albrecht (2001), "Nazi Economic Imperialism and the Exploitation of the Small: Evidence from Germany's Secret Foreign Exchange Balances, 1938-40," Economic History Review 54, 324-345.

Ritschl, Albrecht (2002a), Deutschlands Krise und Konjunktur, 19241934. Binnenkonjunktur, Auslandsverschuldung und Reparationsproblem zwischen Dawes-Plan und Transfersperre, Berlin: Akademie-Verlag. 
Ritschl, Albrecht (2002b), International Capital Movements and the Onset of the Great Depression: Some International Evidence, in: Harold James, ed. The interwar Depression in an International Context, Munich: Oldenbourg.

Ritschl, Albrecht (2003), Dancing on a Volcano: The Economic Recovery and Collapse of the Weimar Republic, in: Theo Balderston, ed. World Economy and National Economies in the Interwar Slump, London: Macmillan.

Ritschl, Albrecht (2005), The Pity of Peace: Germany's War Economy, 1914-1918 and Beyond, in: Stephen N. Broadberry and Mark Harrison, eds., The Economics of World War I, Cambridge: Cambridge University Press.

Sargent, Thomas (1982), The End of Four Big Inflations, in: Thomas Sargent, ed. Rational Expectations and Inflation, New York: Harper \& Row.

Schnabel, Isabel (2004), "The German Twin Crisis of 1931," Journal of Economic History 64, 822-871.

Schubert, A. (1991), The Credit-Anstalt Crisis of 1931, New York:

Cambridge University Press.

Schuker, S. (1976a), The End of French Predominance in Europe, Chapel Hill: University of North Carolina Press.

Schuker, S. (1988), American Reparations to Germany, 1924-1933, Princeton: Princeton University Press.

Schuker, Stephen (1976b), Finance and Foreign Policy in the Era of the German Inflation, in: Otto Büsch and Gerald Feldman, eds., Historische Prozesse der deutschen Inflation 1914-1924, Berlin: de Gruyter, 343-361.

Sicsic, P. (1993), "Was the Franc Poincaré Undervalued?," Explorations in Economic History 29, 69-92. 
Toniolo, Gianni (2005), Central Bank Cooperation at the Bank for International Settlements, 1930-1973, Cambridge: Cambridge University Press.

Webb, S.N. (1989), Hyperinflation and Stabilization in Weimar Germany, Oxford: Oxford University Press.

White, Eugene (2001), "Making the French Pay: the Cost and Consequences of Napoleonic Reparations," European Review of Economic History 5, 337-365. 


\section{LONDON SCHOOL OF ECONOMICS}

\section{ECONOMIC HISTORY DEPARTMENT WORKING PAPERS}

(from 2006 onwards) For a full list of titles visit our webpage at http://www.lse.ac.uk/

2006

WP93 Harbingers of Dissolution? Grain Prices, Borders and Nationalism in the Hapsburg Economy before the First World War

Max-Stephan Schulze and Nikolaus Wolf

WP94 Rodney Hilton, Marxism and the Transition from Feudalism to Capitalism

S. R. Epstein

Forthcoming in C. Dyer, P. Cross, C. Wickham (eds.) Rodney Hilton's Middle Ages, 400-1600 Cambridge UP 2007

WP95 Mercantilist Institutions for the Pursuit of Power with Profit. The Management of Britain's National Debt, 1756-1815 Patrick Karl O'Brien

WP96 Gresham on Horseback: The Monetary Roots of Spanish American Political Fragmentation in the Nineteenth Century Maria Alejandra Irigoin

2007

WP97 An Historical Analysis of the Expansion of Compulsory Schooling in Europe after the Second World War Martina Viarengo

WP98 Universal Banking Failure? An Analysis of the Contrasting Responses of the Amsterdamsche Bank and the Rotterdamsche Bankvereeniging to the Dutch Financial Crisis of the 1920s

Christopher Louis Colvin

WP99 The Triumph and Denouement of the British Fiscal State:

Taxation for the Wars against Revolutionary and Napoleonic France, 1793-1815. Patrick Karl O'Brien 
WP100 Origins of Catch-up Failure: Comparative Productivity Growth in the Hapsburg Empire, 1870-1910 Max-Stephan Schulze

WP101 Was Dick Whittington Taller Than Those He Left Behind? Anthropometric Measures, Migration and the Quality of life in Early Nineteenth Century London Jane Humphries and Tim Leunig

WP102 The Evolution of Entertainment Consumption and the Emergence of Cinema, 1890-1940 Gerben Bakker

WP103 Is Social Capital Persistent? Comparative Measurement in the Nineteenth and Twentieth Centuries Marta Felis Rota

WP104 Structural Change and the Growth Contribution of Services: How Motion Pictures Industrialized US Spectator Entertainment Gerben Bakker

WP105 The Jesuits as Knowledge Brokers Between Europe and China (1582-1773): Shaping European Views of the Middle Kingdom Ashley E. Millar

WP106 Regional Income Dispersion and Market Potential in the Late Nineteenth Century Habsburg Empire Max-Stephan Schulze

2008

WP107 'The Big Problem of the Petty Coins', and how it could be solved in the late Middle Ages

Oliver Volckart

WP108 The Anglo-German Industrial Productivity Puzzle, 1895-1935: A Restatement and a Possible Resolution Albrecht Ritschl

WP109 The History, Nature and Economic Significance of an Exceptional Fiscal State for the Growth of the British Economy, 1453-1815 Patrick O’Brien 
WP110 The Economic History of Sovereignty: Communal Responsibility, the Extended Family, and the Firm Lars Boerner and Albrecht Ritschl

WP111 A Stakeholder Empire: The Political Economy of Spanish Imperial Rule in America Regina Grafe and Alejandra Irigoin

WP112 The U.S. Business Cycle, 1867-1995: Dynamic Factor Analysis vs. Reconstructed National Accounts Albrecht Ritschl, Samad Sarferaz and Martin Uebele

WP113 Understanding West German Economic Growth in the 1950s Barry Eichengreen and Albrecht Ritschl

2009

WP114 War and Wealth: Economic Opportunity Before and After the Civil War, 1850-1870

Taylor Jaworski

WP115 Business Cycles and Economic Policy, 1914-1945: A Survey Albrecht Ritschl and Tobias Straumann 